\title{
Structural description of sections
}

The Rubjerg Knude Glaciotectonic Complex is differentiated into 13 structural sections, which are named after the localities recorded in the geological crosssection of Lønstrup Klint by Jessen (1918). The sections can be grouped into three zones within the complex: a distal zone (three sections farthest to the south), a central zone (seven sections in the middle part of the complex), and a proximal zone (three sections farthest to the north). They are named, from south (near Nørre Lyngby) to north (at Lønstrup): Ulstrup, Stensnæs, Martørv Bakker, Kramrende, Brede Rende, Sandrende, Stenstue Rende, Grønne Rende, Rubjerg Knude Fyr, Stortom, Moserende, Mårup Kirke and Ribjerg Sections. Three criteria were used for defining the sections: (1) the sections had to be bordered by marked footwall ramps, (2) each section should be characterised by uniform structural architecture, and (3) the sections had to be descriptively and geographically delimited. A good example of the first criteria is the steep thrust fault separating the Sandrende Section from the Stenstue Rende Section. As an example of a uniform architecture, the Grønne Rende Section can be mentioned, and finally the Mårup Kirke Section includes the long barren stretch from the Mårup church to Ribjerg at Lønstrup where the lack of geographical markers as well as characteristic footwall ramps is significant.

Each section is described separately, a general physiographic introduction being followed by four parts: (1) tectonicarchitecture, (2) sedimentary units, (3) structures, and (4) interpretation of structural development. The first descriptive part provides a general description of the macro-structures. The second part presents the sedimentary deposits, and although to some degree it repeats the lithostratigraphic descriptions of the formations (see above), the detailed observations of syntectonic sedimentation are relevant to an appreciation of the structural development in the individual sections. The third part concems the description of meso- and mini-structures (thrust faults, folds, faults, shear zones, joints, fractures, breccias, polydiapirs etc.). The description of each section is concluded with an interpretation of the formation of the structures. This interpretation should not be confused with the overall interpretation of the dynamic development of the progressive thrust-fault deformation that follows the systematic descriptions of the sections. The organisation of the section descriptions follows the general systematics of structural geology: the description of geometry, the kinematic investigation, interpretation of the dynamics and finally the analysis can be concluded by a tectonic synthesis (Dennis 1972).

The reader should note that the structural elements are numbered from distal to proximal. This is a consequence of the systematic analysis; in order to obtain an overview, the reader can compare the structural description given for each section with the dynamic development presented in the latter part of this bulletin.

\section{Ulstrup Section}

The southern frontal edge of the Rubjerg Knude Glaciotectonic Complex is positioned in the Ulstrup Section where the undeformed foreland is exposed below the hanging-wall flat of the last displaced and most distal thrust sheet (UL01, see Plate 2). One of the most interesting problems addressed in the analysis of this complex is the presence of two long thin thrust sheets that were translated southwards for about $500 \mathrm{~m}$ from their ramps to their present positions without complete internal disruption. The Ulstrup Section represents the foreland margin of the thrust-fault complex, and the two flat-lying thrust sheets extend from the southern edge of the thrust front at Tvonnet Rende to the steep ramp thrust separating the Ulstrup and Stensnæs Sections (Plate 1). The Stensnæs ramp thrust was initially regarded as the foreland thrust (Pedersen 1987), but new outcrops of the southem Ulstrup thrust exposed in 1996 and 1997 clearly demonstrated additional details of the frontal thrusting. Consequently, the long cliff section showing horizontal bedding that had previously been regarded as a primary, undeformed sedimentary unit (Fig. 42) is now interpreted as a displaced thrust sheet (UL01).

The Ulstrup Section is truncated by a broadly horizontal glaciotectonic and erosional unconformity above which aeolian sand was deposited, either as sheet sands or as small dunes, up to $10 \mathrm{~m}$ high. 


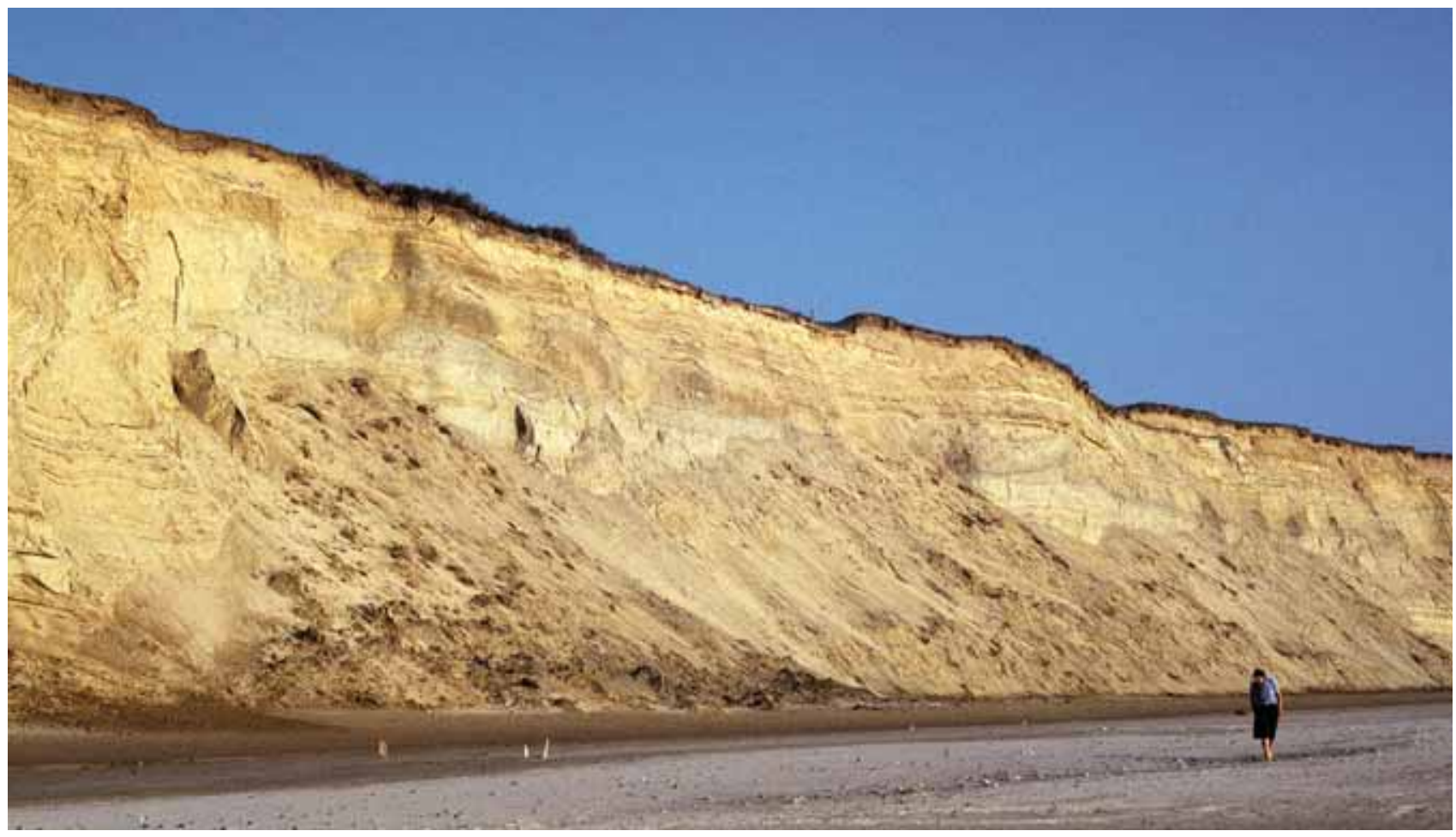

Fig. 42. The steep sandy cliff of the Ulstrup Section displays horizontal bedding of an apparently undisturbed deposit. However, structural analysis of thrust-fault relationships to the south indicates that it is a long flat thrust sheet displaced more than $500 \mathrm{~m}$ towards the foreland to the south. The cliff section is $25 \mathrm{~m}$ high and the view is towards the south. Photograph: June 1984.

\section{Tectonic architecture}

The Ulstrup Section comprises the two flat-lying thrust sheets, UL01 and UL02. The tip line of the hangingwall ramp (the edge of the frontal thrust) is situated on the northern side of Tvonnet Rende (for location, see Plate 1). Unfortunately, the precise position is obscured by late, syntectonic erosion and sedimentation at the front of the thrust-fault complex, as well as by sand scree covering the outcrops at Tvonnet Rende. The northern boundary of the section is the footwall ramp and flat of the UL02 thrust sheet, which forms a transitional zone of imbricate thrusting related to the frontal part of the Stensnæs Section.

The frontal part of the UL01 thrust sheet was displaced from the upper footwall ramp (Fig. 43) along an upper footwall flat on the top surface of the foreland. At the tip of the thrust sheet, the thrust fault dips gently towards the foreland, and a small foreland-dipping ramp is also located at point $6040 \mathrm{~m}$ in the crosssection (Plate 1, see Fig. 50). The ramps probably formed due to erosion in front of the propagating thrust-fault edge. In the central part of the UL01 thrust sheet, a synform structure is associated with a chaotic breccia, interpreted as the collapse of a frost mound or sand- mud diapir below the thrust fault; the synformal depression is referred to hereafter as Ulstrup Rende (for location, see Plate 1). The trailing end of the thrust sheet starts at the upper footwall ramp of the foreland from where the hanging-wall flat is inferred to continue along the footwall flat to the footwall ramp at its trailing end. The total length of the thrust sheet is about $750 \mathrm{~m}$ and the displacement is estimated at 350 $\mathrm{m}$, which is the distance from the footwall ramp at point $5800 \mathrm{~m}$ in the cross-section to the frontal termination in Tvonnet Rende (Plate 1). The thickness of the thrust sheet varies from 10 to $20 \mathrm{~m}$, decreasing towards the tip to the south, and increasing in thickness where syntectonic deposits fill the piggyback basin on the back of the thrust sheet. The thickness of the Lønstrup Klint Formation is only $6 \mathrm{~m}$ in the southern part of the piggyback basin due to erosion related to elevation during thrust faulting.

The UL02 thrust sheet is $600 \mathrm{~m}$ long, with the frontal edge situated on the northern side of the UL01 piggyback basin at point $5900 \mathrm{~m}$, and the trailing end disappearing into the décollement zone at point 5300 $\mathrm{m}$. The thrust fault consists of a more than $400 \mathrm{~m}$ long footwall flat on top of UL01 extending from the footwall ramp hinge at point $5360 \mathrm{~m}$ southwards to the 


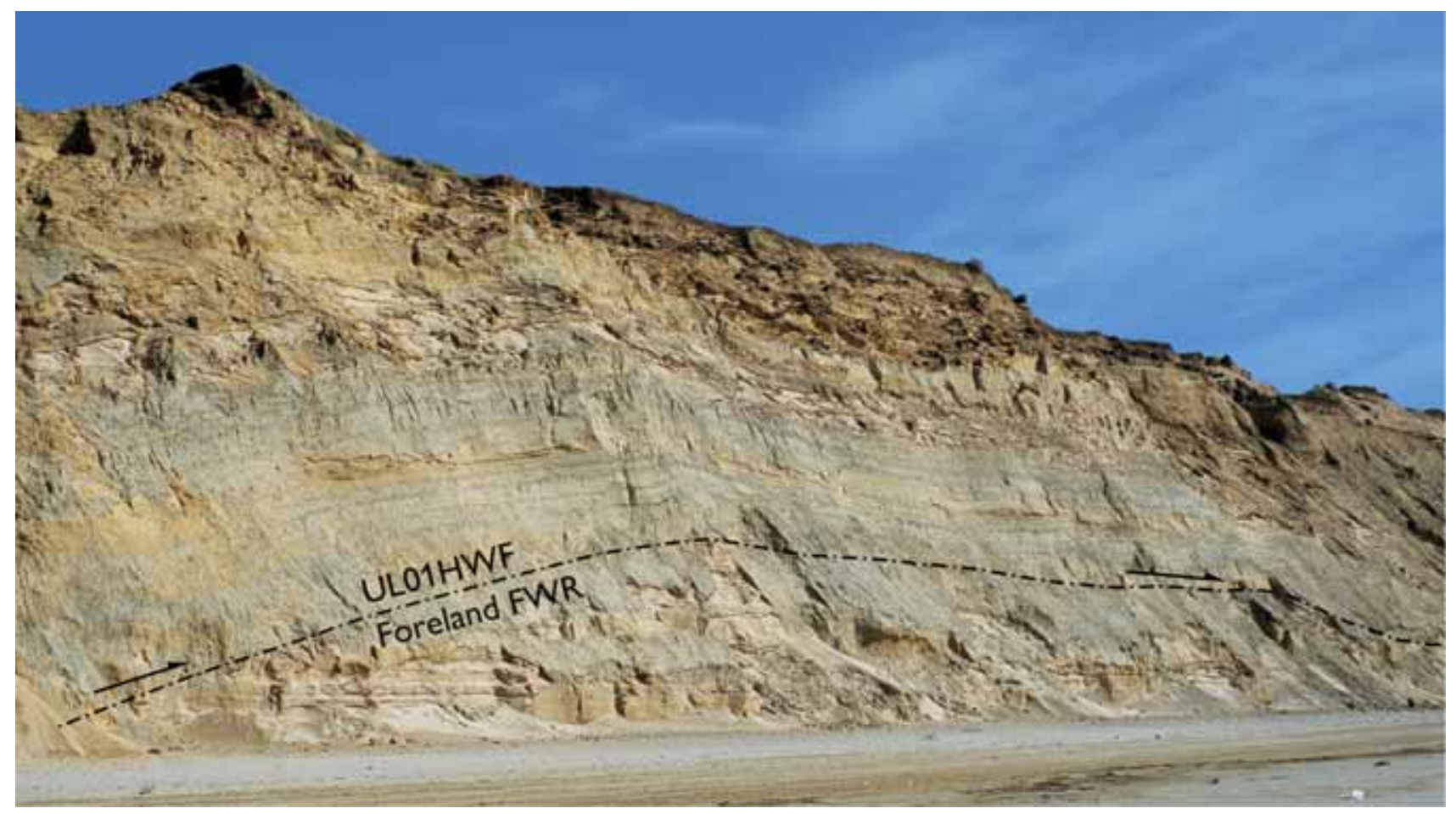

Fig. 43. The upper footwall ramp of the foreland (Foreland FWR) along which the UL01 thrust fault propagated (UL01HWF: Ulstrup thrust sheet 01 hanging-wall flat), and from where it continued for more than $300 \mathrm{~m}$ over the footwall flat of the foreland. The cliff section is $25 \mathrm{~m}$ high and south is to the right. Photograph: May 1998.

gently dipping frontal bend at point $5780 \mathrm{~m}$ in the cross-section (Plate 1). The frontal bend corresponds to the hinterland-dipping limb of the flat-topped hanging-wall anticline of UL01. This hanging-wall anticline compares well with the structure of the thrust-fault model in Fig. 6, and the southernmost c. $100 \mathrm{~m}$ of UL02 can be regarded to have been emplaced piggyback on UL01 during the translation over the frontal footwall ramp. The UL02 thrust sheet is only 5-6 m thick above the flat-topped anticline, whereas the thickness increases to $20 \mathrm{~m}$ at the trailing-end ramp. The displacement along the northern thrust fault is $550 \mathrm{~m}$, with an uncertainty of 10-25 m depending on the interpretation of the shape of the trailing-end ramp and the amount of erosion of the frontal part at the piggyback basin at Ulstrup Rende.

\section{Sedimentary units}

The sedimentary units in the Ulstrup Section comprise the upper part of the Lønstrup Klint Formation, erosional remnants of the lower part of the Rubjerg Knude Formation, and a variety of intercalations of the Rubjerg Knude Formation distinguished here as the
Ulstrup beds. The L/R-unconformity between the Lønstrup Klint and Rubjerg Knude Formations can be traced along the upper part of the UL01 thrust sheet in which it also forms the base of the piggyback basin. A few younger erosional unconformities, below and above the Ulstrup beds, are of only local significance within the Ulstrup Section.

\section{Lønstrup Klint Formation}

The mud-dominated Lønstrup Klint Formation forms the main part of the thrust sheets in the Ulstrup Section, and has an average thickness of about $10 \mathrm{~m}$ (Fig. 19). In the southem thrust sheet, the fine-grained sand beds are thin and only small-scale current ripples have been observed. A combination of load structures (balland-pillow) and waterescape structures (convolution and small-scale diapirs) are developed at certain horizons. Above the hanging-wall flat, a zone about $2 \mathrm{~m}$ thick takes the form of a mobilised mud breccia, which can be characterised as a sole thrust zone. This breccia is superimposed by beds affected by a brittle type of brecciation, forming cracks and joints in an up to 4 $\mathrm{m}$ thick zone in the lower part of the thrust sheet. 
Fig. 44. The mud-mobilised thrust-zone breccia consists of structureless mud with scattered clasts floating in the matrix. Dilation cracks filled with sand are superimposed on the mud-mobilised brecciation fabric. This reflects two phase of cataclastic deformation: a first phase of water-over-pressured brecciation (hydrodynamic brecciation), and a second phase of brittle fracturing when the mud was consolidated, dehydrated or perhaps frozen. Handle of spade is $12 \mathrm{~cm}$. Photograph: June 1997.

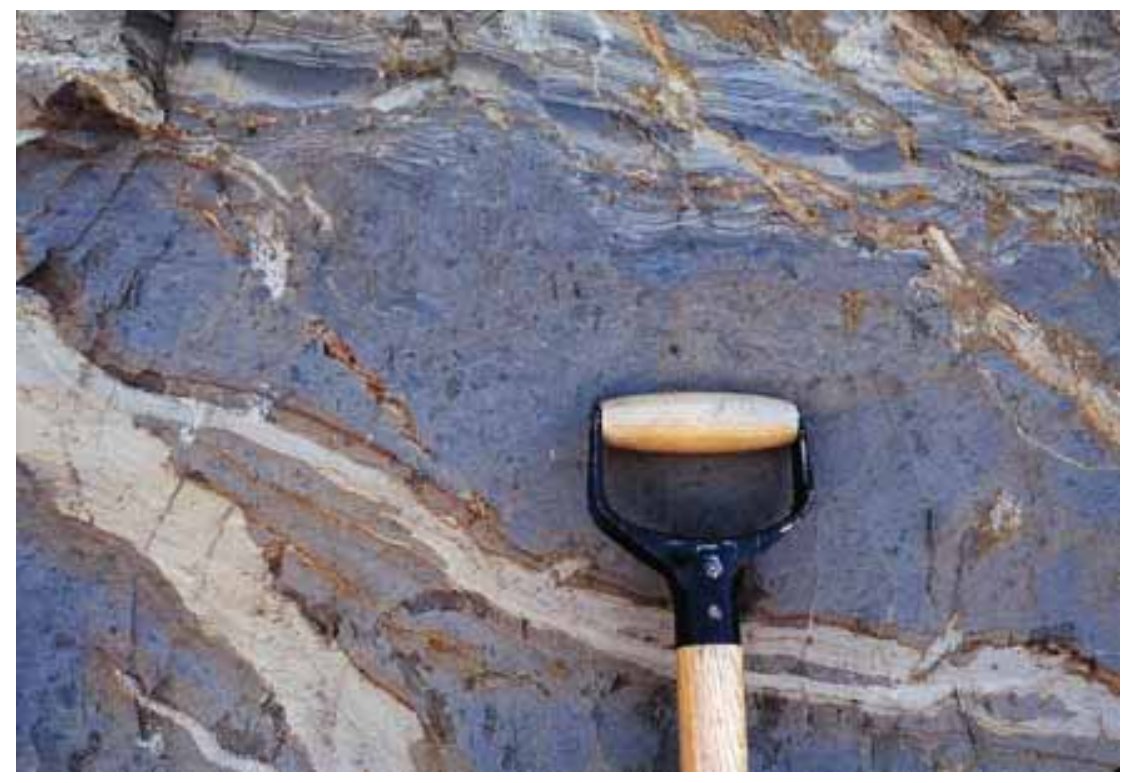

The northern thrust sheet (UL02) displays a more sandy part of the Lønstrup Klint Formation (Fig. 25). Here the sand beds are up to $1 \mathrm{~m}$ thick and waterescape structures, convolute bedding and flame structures commonly disturb the primary bedding. Balland-pillow structures are more common towards the trailing end of the thrust sheets.

\section{Rubjerg Knude Formation}

In the Ulstrup Section, the Rubjerg Knude Formation comprises three different depositional units: the main 'background' sedimentation of outwash sand, the glaciolacustrine Ulstrup beds (Fig. 25), and the coarsegrained glaciofluvial Ulstrup beds (Fig. 20).

The main depositional unit is fine- to mediumgrained meltwater sand represented in the footwall block of the foreland (Fig. 43). Small-scale current ripples occur in the parallel bedded sand, which is interlayered with c. $0.5 \mathrm{~m}$ thick trough cross-stratified beds.

The glaciolacustrine Ulstrup beds form a 3-5 m thick unit that is only found on the back of the UL02 thrust sheet (Fig. 25). This unit consists of dark bluish grey, laminated clayey mud interlayered with a few sandy beds up to $0.5 \mathrm{~m}$ in thickness. The unit was deposited on a bedding-parallel unconformity, which is only discordantly developed in the northernmost trailing part of thrust sheet UL02. The unit thins out towards the south, and disappears near the hinterland-dipping limb of the flat-topped hanging-wall anticline formed above the footwall ramp of the foreland. Intraforma- tional hydrodynamic brecciation, including small-scale diapirs and slump-like features, deformed the clayey mud; such deformation is not seen in the Lønstrup Klint Formation below the unit.

The glaciofluvial Ulstrup beds occur in the Ulstrup Rende depression between points 5900 and $6000 \mathrm{~m}$ in the cross-section (Plate 1). This unit is a c. $8 \mathrm{~m}$ thick succession of meltwater gravel fining up into coarse-grained sand (Fig. 20). Large-scale trough crossbedding dominates the succession and clasts up to boulder size occur in the lowermost $2 \mathrm{~m}$ (Fig. 28). Lithologically, the clasts are dominated by flint, but clasts of fossil frozen sand are abundant (Fig. 29).

The glaciofluvial Ulstrup beds are overlain by c. 5 $\mathrm{m}$ of medium- to coarse-grained sand of the Rubjerg Knude Formation. On the north side of the Ulstrup Rende depression, between points 5900 and $6000 \mathrm{~m}$, slump-folded sand beds and sedimentary breccias occur in the upper part of this succession, suggesting gravity gliding down the steep slope of the depression (piggyback basin of UL01).

\section{Structures and breccias}

The most important structures related to the thrust faults in the Ulstrup Section are the breccias occurring in the thrust zones above the thrust-fault surfaces. They appear to have formed by collapse of the thrust sheet during translation. The low-angle anastomosing faults that developed in the most distal part of the thrustfault complex originated similarly during translation 


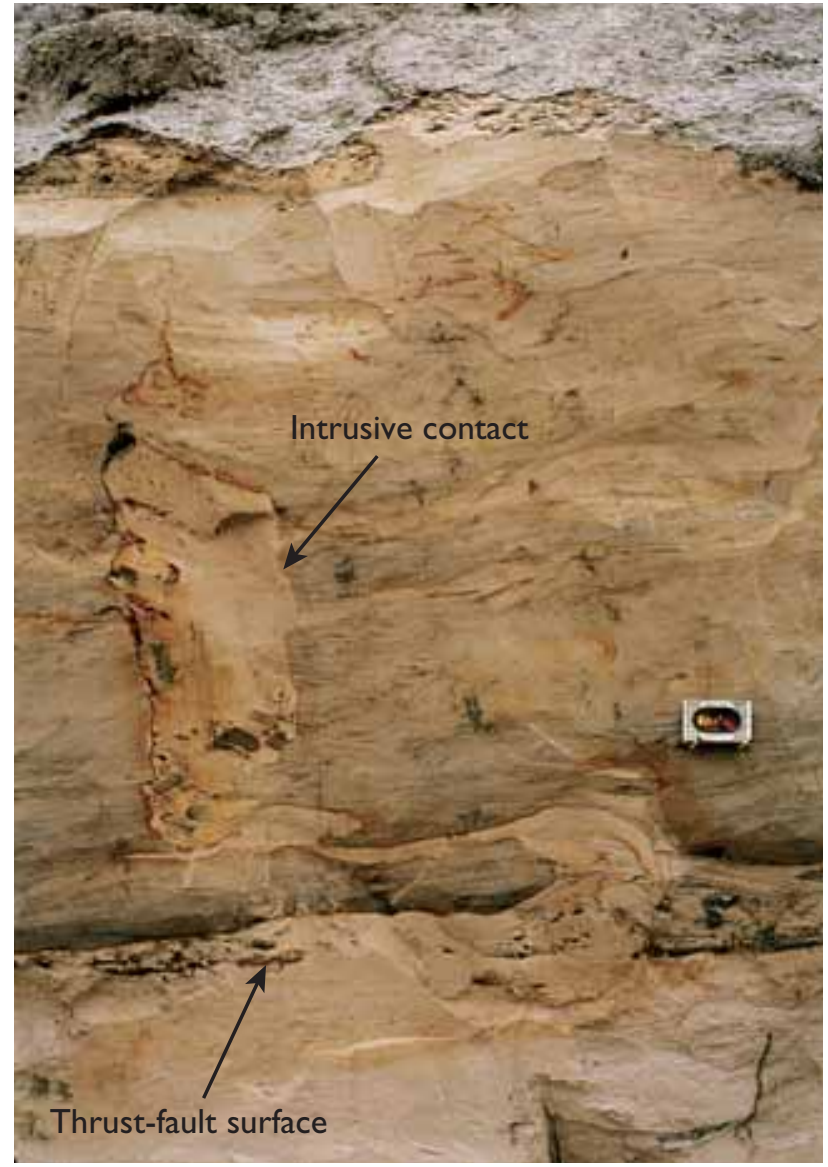

Fig. 45. Mud mobilisation along the hanging-wall flat of the UL02 thrust sheet. From the thrust-fault surface, a sandy mud fluid intruded along fractures and up into the lower part of the thrust sheet where it formed a mud-intrusion. During the initial hydrodynamic brecciation of the thrust zone, small relict segments remained at the thrust plane where they were modified and developed into elongate cataclasts in the sole of the thrust breccia zone. Photograph: July 1998; matchbox for scale.

and are associated with southerly dipping normal faults. A significant collapse structure that formed beneath the Ulstrup Rende depression is also worthy of note.

\section{Thrust-zone breccias}

The thrust-zone breccias occur above the hangingwall flat of the UL01 and UL02 thrust sheets, where they affect the mud-dominated Lønstrup Klint Formation. The thrust zone is up to $4 \mathrm{~m}$ thick in the most distal part of the thrust-fault system (southern part of UL01), and decreases in thickness to $1 \mathrm{~m}$ northwards; it can be traced along the hanging-wall flat of UL02 for a considerable distance. The thrust-zone breccia consists of mobilised mud with irregular clasts of mud scattered throughout (Fig. 44). Some patches may be more sandy and others more clayey, and lenses and layers of sand may be present. The mobilisation was apparently initiated as sandy mud-fluid that developed at the thrust-fault surface and extended up into the sedimentary unit (Fig. 45). In many cases, the initial hydrodynamic brecciation of the thrust zone left segments along the displacement surface of the thrust fault, which were modified and developed into elongated cataclasts along the sole of the breccia zone. Convolute bedding and small-scale diapirism are also present.

The mobilised mud was subsequently transected by dilation cracks and sand-filled fissures (Fig. 46). The dilation cracks form an irregular network and the sand-fill was injected into consolidated mud (Figs 44, $46,47)$. More or less horizontal sand-filled cracks have been observed in the frontal part of the UL01 thrust sheet, where they are up to $15 \mathrm{~cm}$ thick and appear up to $1 \mathrm{~m}$ above the hanging-wall flat. The sand in the cracks shows planar horizontal lamination and small-scale current ripples and a few vertical sandfilled pipes extend upwards from the cracks (Fig. 48).

Towards the frontal tip of the UL01 thrust sheet, an increasing number of bedding parallel or low-angle anastomosing fractures and small-scale faults appear to be related to an increased rate of internal gliding. This is an indication of how close the thrust sheet was to disintegration and a loss of cohesion. Zones 0.2-0.5 m thick, grading into mobilised mud, occur in between the anastomosing fractures, resulting in the destruction of bedding (Fig. 49).

\section{Foreland-dipping hanging-wall flat faults}

In the frontal part of the UL01 thrust zone, forelanddipping faults become increasingly common. These faults are either foreland-dipping $\left(20-30^{\circ} \mathrm{S}\right)$ ramps formed by the hanging-wall flat scouring into the footwall flat (Fig. 50), or sets of $50^{\circ} \mathrm{S}$ dipping normal faults with displacements of about $10 \mathrm{~cm}$. These structures are considered to be the result of partial collapse of the tip of the foreland-dipping limb of the hangingwall ramp above a low-angle hanging-wall ramp translated along the footwall flat of the foreland. 


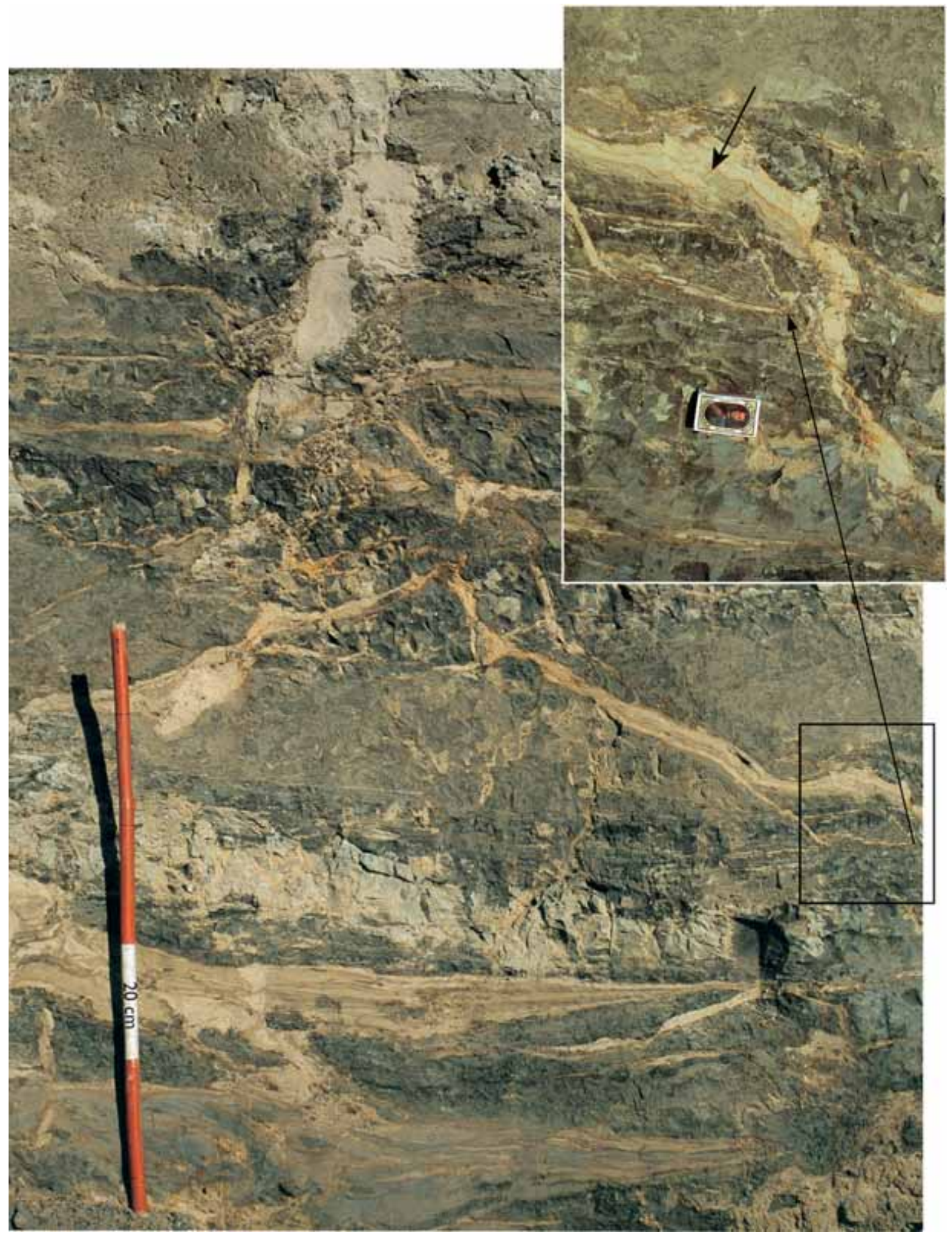

Fig. 46. Subsequent to mud mobilisation, the thrust zone was transected by dilation cracks and fissures, which form an irregular network into which sand was 'injected'. The mobilised mud had clearly become consolidated before the sand-filled cracks formed. The close-up inset illustrates the 'reverse' drag of the sand-fill (arrowed) indicating an upward direction of flow in the fissure. Photograph: May 1998. 

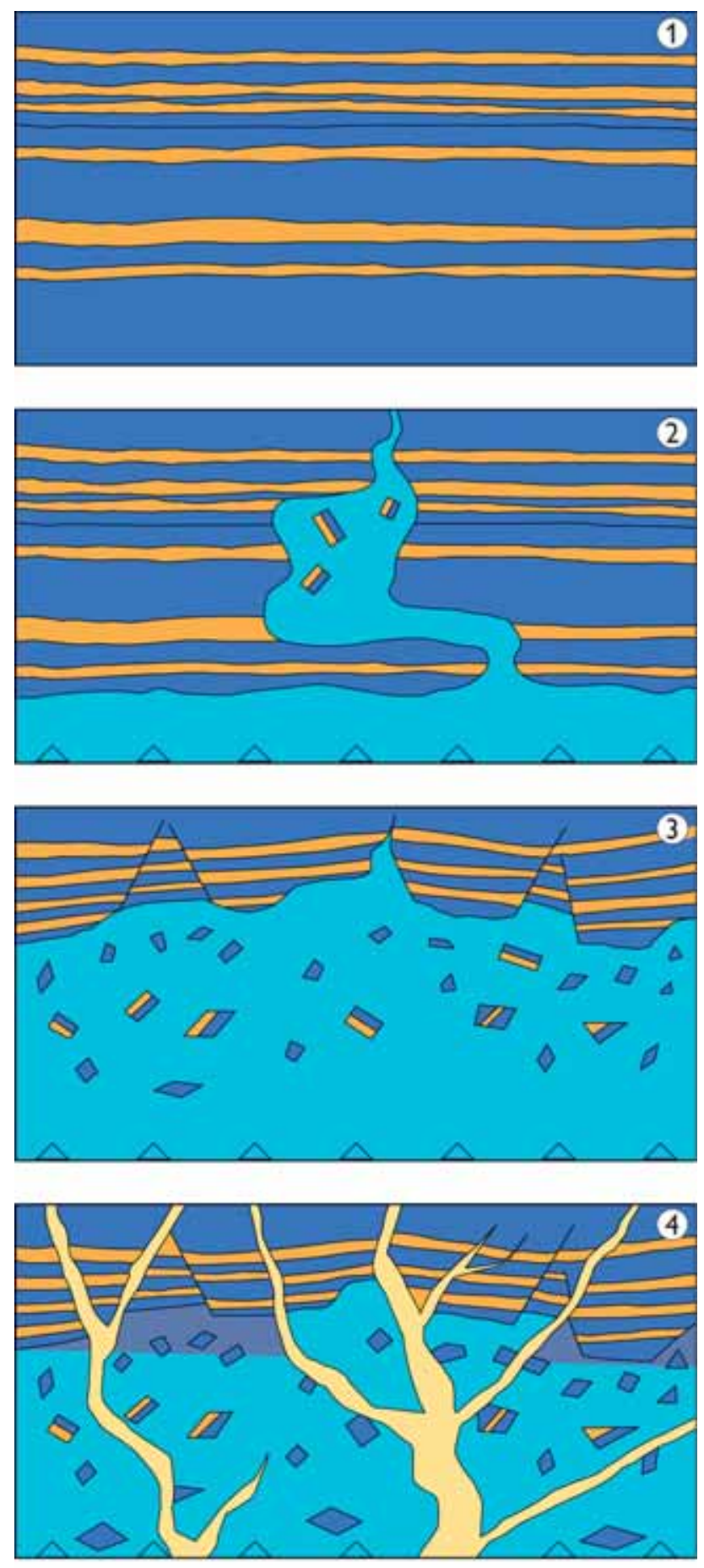

Clayey mud

Sand

\section{Collapse structure in the Ulstrup Rende}

Structures in the central part of Ulstrup Rende (Figs $51,52)$ are interpreted to represent a collapsed diapir. Theearly phase structures include thinning of the Lønstrup Klint Formation in the thrust sheet, and formation of concave troughs in its surface. Vertically or steeply dipping sand breccias with upward directed flow structures cross-cut the thrust-zone breccia. The appearance of structurelesssand pockets indicates sandfill of mobilised sediment from an over-pressured zone in the subsurface. The complex of breccias and reorientated bedding is interpreted as a collapse structure; it is considered to be responsible for the formation of the Ulstrup Rende depression, and the disruption of the thrust sheet along steeply dipping fractures. In the breccia zone, steeply dipping sand-filled cracks and normal faults formed prior to the continued deposition of the Rubjerg Knude Formation in the depression.

On the southern side of the Ulstrup Rende depression, the muddy part of the thrust sheet is displaced by steeply dipping normal faults. Downthrow is to the south, synthetic towards the depression, and the faults are thought to be related to the collapse of the diapir structure.

\section{Interpretation of structural development}

There are two reasons why the Ulstrup Section deserves special attention. The first is that it represents a foreland thrust section with long lateral transport of thin thrust sheets, the nature of which has not previously been documented. Secondly, it demonstrates the likely development of the initial stages of deformation, which the remainder of the thin-skinned thrust faulting in the Rubjerg Knude Glaciotectonic Complex also experienced before the uppermost part was eroded. Thus the first phase of thrust-fault deformation is preserved here whereas it is almost never represented in the thrust-fault sections that have been

Fig. 47. The formation of thrust-zone breccias in the distal part of the thrust-fault complex is here illustrated in four stages of development. (1) The initial undeformed sediment (Lønstrup Klint Formation) comprises clayey mud interlayered with thin sand beds. (2) A mud-fluid is formed above the thrust-fault surface (line with open triangles) from where it is injected up into the layers above (see Fig. 45). (3) Increasing mud-mobilisation results in the formation of a structureless matrix with dispersed matrixsupported clasts of the primary sediment (see Fig. 44). Note the small normal faults indicating an on-going process of collapse. (4) The mobilised mud becomes consolidated and the thrust-zone breccia develops into a more brittle stage; dilation cracks form into which water-saturated sand is injected (see Fig. 46). 
Fig. 48. A subhorizontal sand-filled fracture occurring in the frontal part of the UL01 thrust sheet. The sand-filled fracture appears about $1 \mathrm{~m}$ above the hanging-wall flat; the sand shows planar horizontal lamination and current ripple cross-lamination. The sand-filled fracture is interpreted to have formed during ground-frozen conditions, whereas the vertical sand-filled pipe probably reflects loading of the thrust sheet when it ultimately lost its carrying pore-water pressure and settled on its hanging-wall flat. Photograph: June 1997.

Fig. 49. Subhorizontal anastomosing faulting (centre left) with mud-mobilisation developed in domains between fault fractures in the frontal part of the UL01 thrust sheet. Photograph: June 1997.
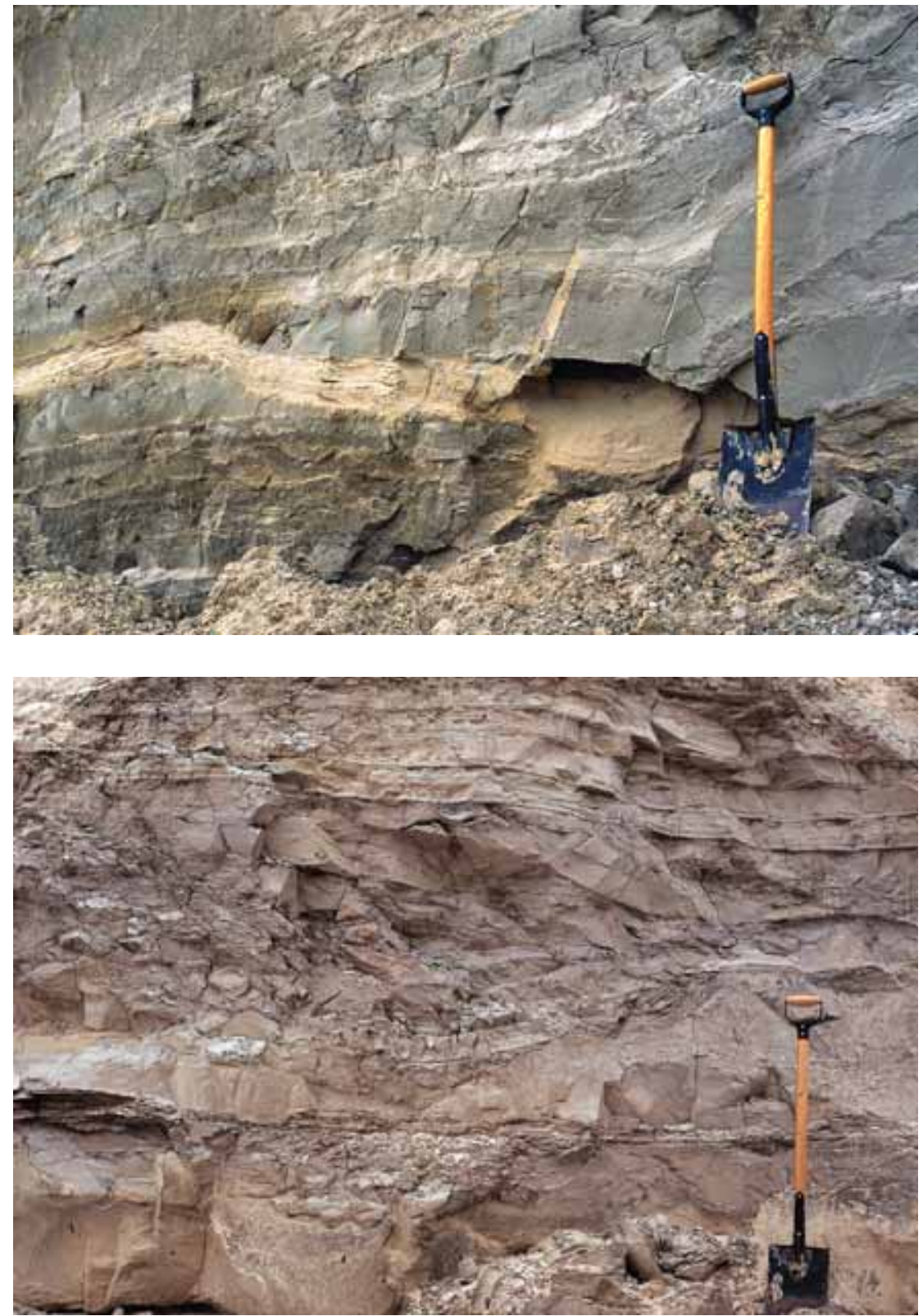

more intensely deformed. The interpretation of the structural development can be summarised in the following nine stages.

1. Initial thrust-fault fracturing and thrust-fault propagation took place during mobilisation of mud along the hanging-wall flat. At this stage, the thrust-zone breccia was formed due to high pore-water pressure in an unfrozen stage.

2. The UL01 and UL02 thrust sheets probably started to move along the décollement zone as one coherent thrust sheet, and first separated into two thrust sheets after the frontal part of the sheet had passed the most distal foreland footwall ramp.

3. The ramping up of the northern UL02 thrust sheet probably increased the pore-water pressure, and when this increase also affected the frontal part of UL01, diapirism was initiated under the central part of the southern thrust sheet.

4. The diapiric uplift and erosion took place in the elevated surface. This erosion extended through the Rubjerg Knude Formation to locally intersect the L/R-unconformity. The residual coarse clastic gravel 


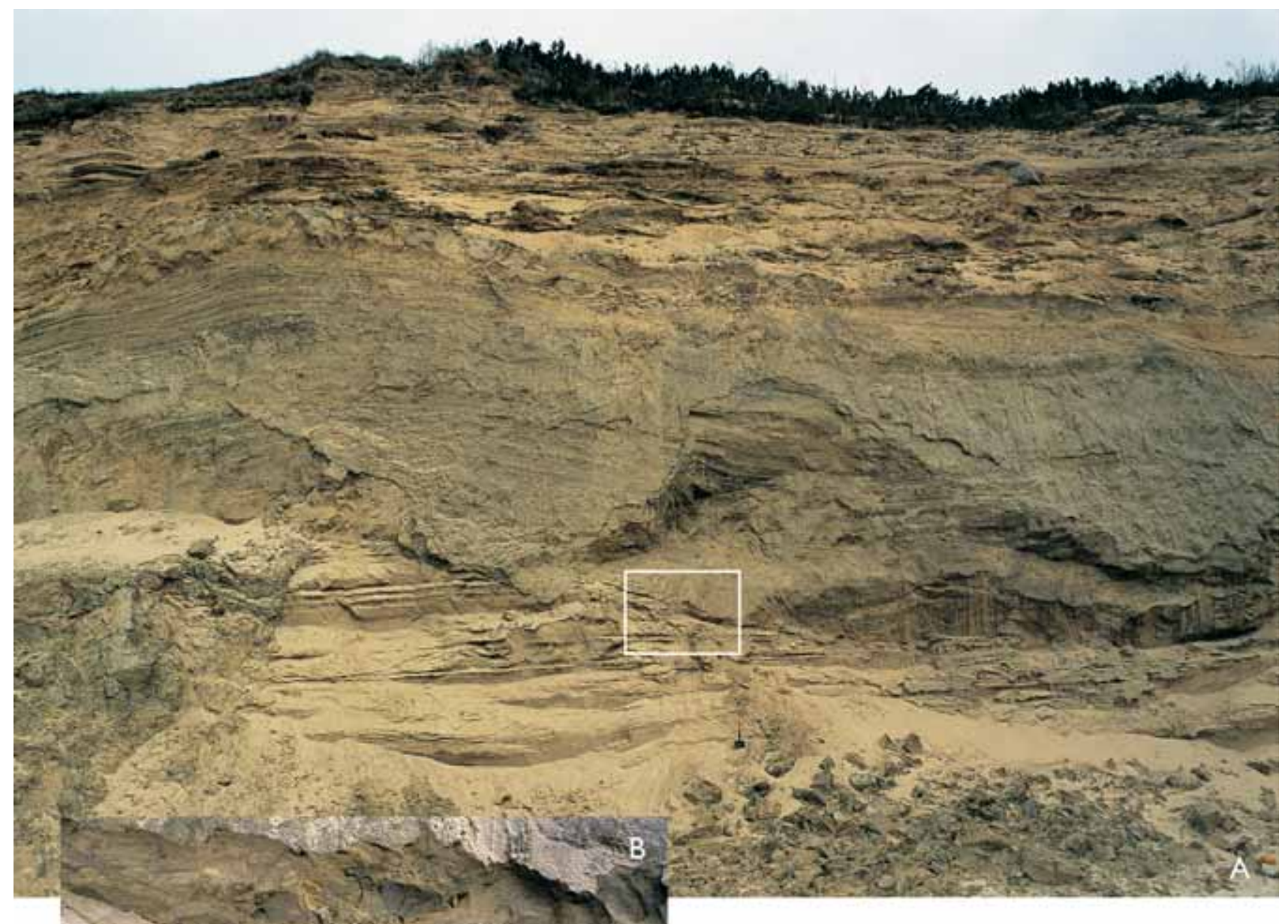

Fig. 50. A: Foreland-dipping ramping of hanging-wall flat formed by scouring-erosion of the footwall flat into the top surface of the foreland. Note in the close-up (B) that some hydrodynamic brecciation occurred in the footwall ramp just below the thrust zone. Photograph: June 1997.

on thefootwall flatat the surface of the foreland in the Ulstrup Section.

7. The consequence of the diapir collapse was the

bed on the unconformity surface was probably the original source for the large amount of coarse-grained material in the Ulstrup Rende depression.

5. The mud-sandvolcano brokethrough to the surface, and the mobilised mud and sand were extruded with the release of the high pore-water pressure.

6. The surface of the diapir collapsed and gravel and sand filled the fractured structure. The collapse was probably contemporaneous with the loss of pore pressure throughout the thrust zone. The release of over-pressure in the thrust zone resulted in the finalsettling of the thrust sheet formation of the depression in Ulstrup Rende. Redeposited coarse-grained clastic material filled the depression, generating the glaciofluvial Ulstrup beds. The occurrence of fossil frozen-sand clasts implies that part of the surface, the Rubjerg Knude Formation, was ground-frozen probably that part of the thrust sheet that had been elevated due to the propagation up over the central ramp. The ground-frozen condition was probably also responsible for freezing of the mobilised mud in the thrust zone and the subsequent development of sand-filled dilation cracks (Fig. 47) 


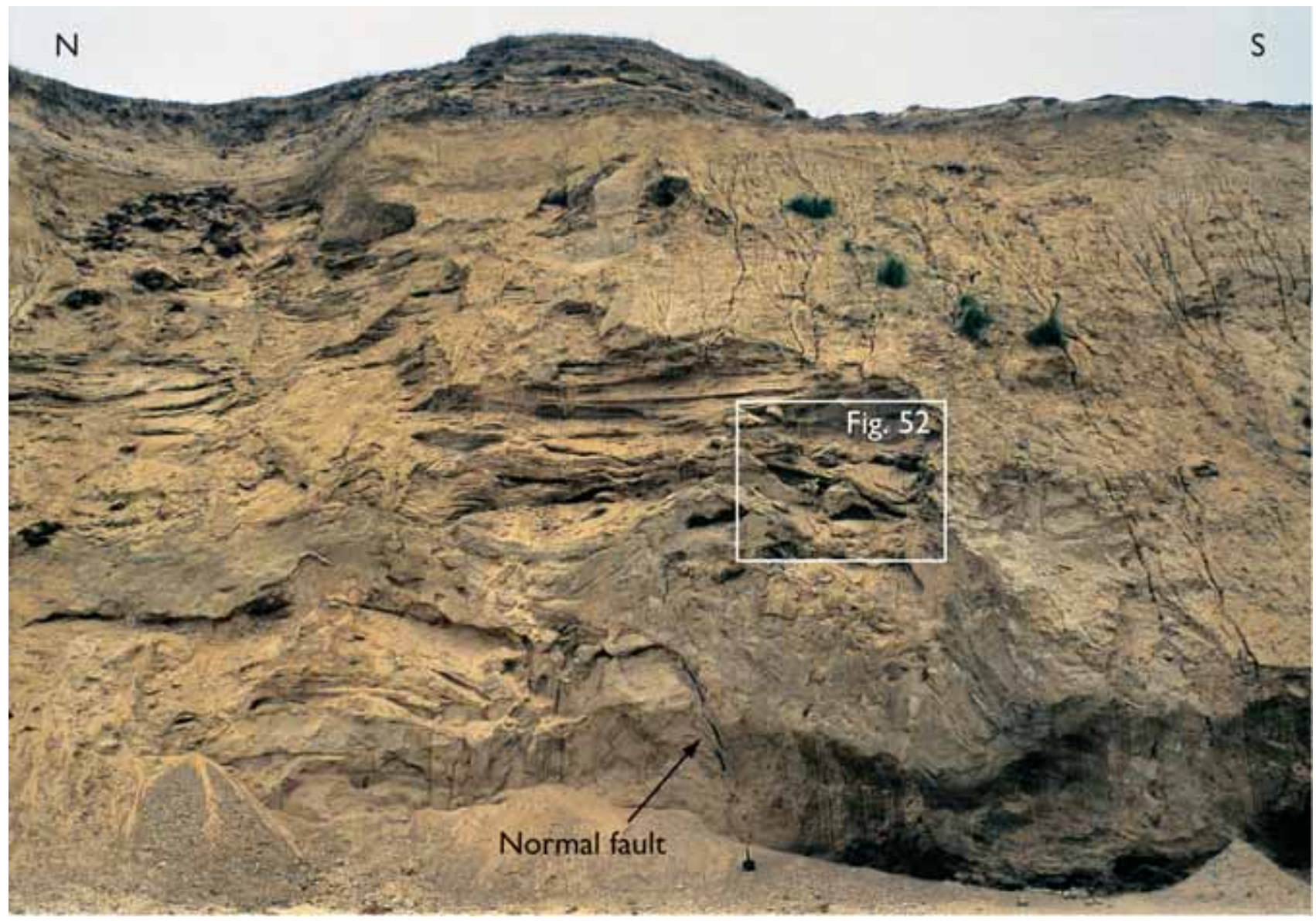

Fig. 51. The Ulstrup Rende depression is interpreted to represent a combination of a piggyback basin (according to the model in Fig. 7) and the collapse of an underlying mud diapir or frost-mound feature. Note the steep normal fault on the left side of the depression (to the north). Photograph: June 1997; spade (lower centre) for scale.

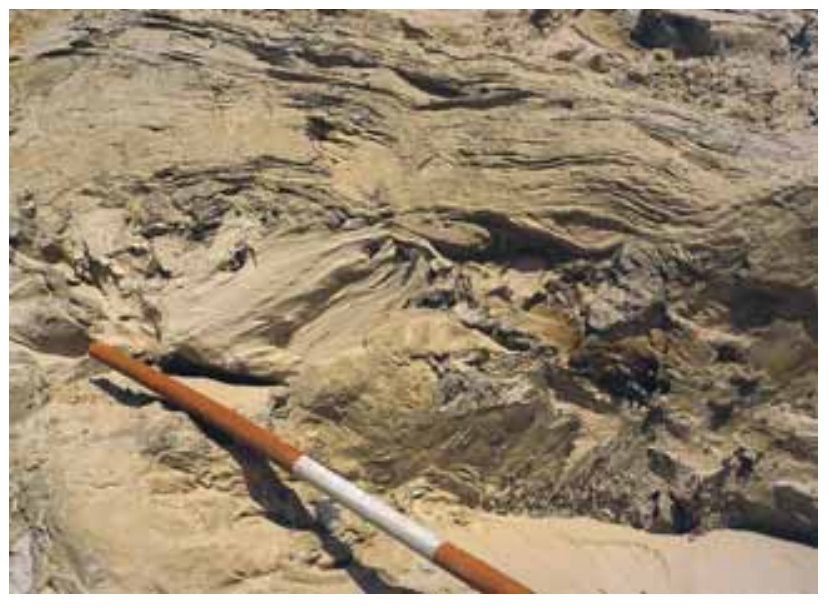

Fig. 52. Chaotic sand/gravel breccia in the centre of the Ulstrup Rende depression, which is interpreted as the result of the collapse of the diapiric structure created in the subsurface below the UL01 thrust sheet. Photograph: May 1998.
8. The depression was ultimately filled by the sand of the upper unit of the Rubjerg Knude Formation. The frontal edge of the northern thrust sheet propagated towards the northern side of Ulstrup Rende and parts of its leading tip slumped down the steep slope of the depression. This indicates the sequential and later movement of the northern thrust sheet. The depression can be interpreted in part as a piggyback basin that formed according to the model demonstrated in Fig. 7.

9. Finally, the uppermost sediments of the Rubjerg Knude Formation covered the section before the glacier advanced across the area. The uppermost metre of sand was transformed into a glaciofluvialsand-glacitectonite. 


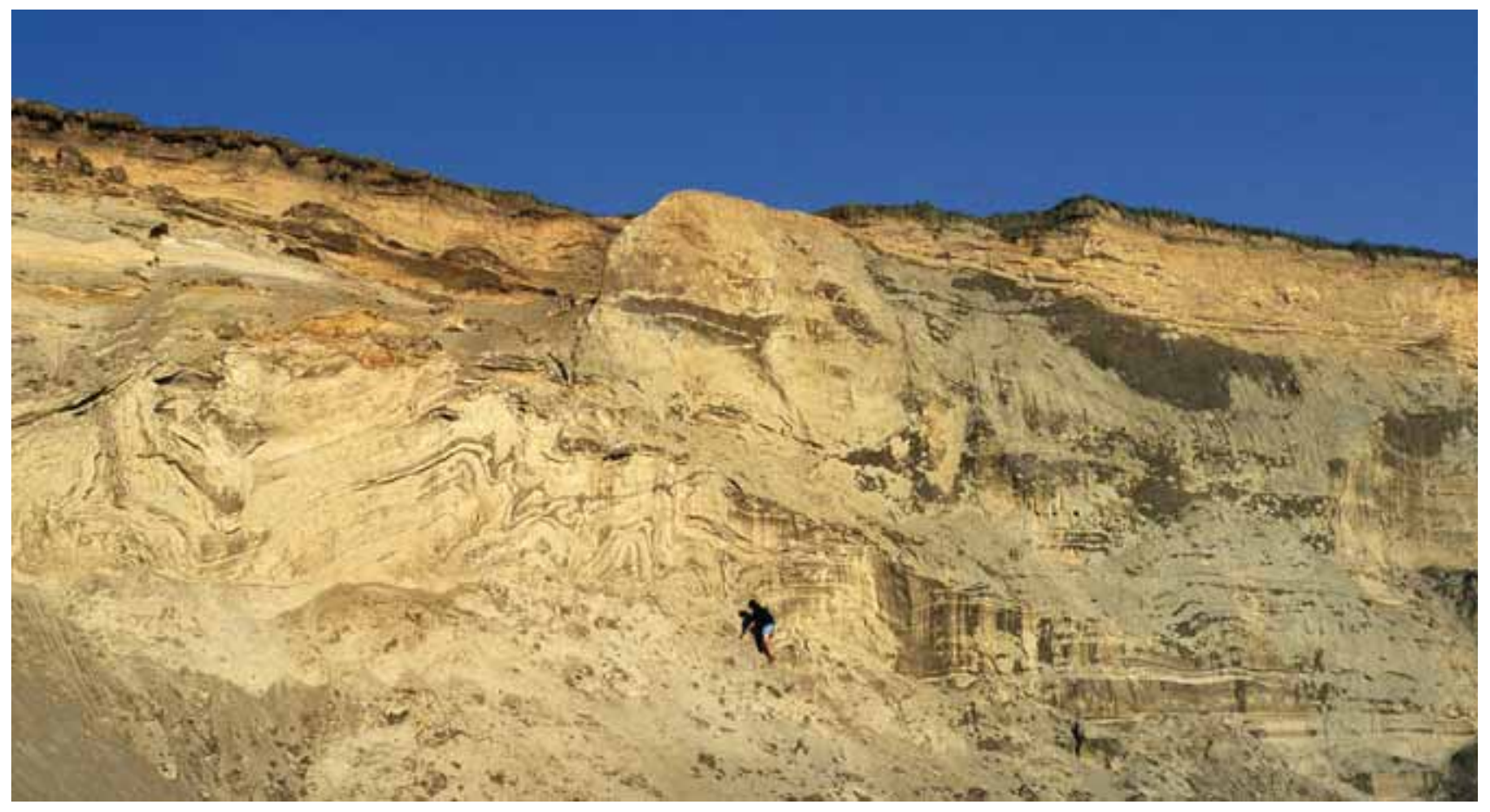

Fig. 53. The fold complex developed in the transitional imbricate zone between Ulstrup and Stensnæs Sections. Note that the thrust faults acting as flexural slip surfaces in the folding continue into the bedding-parallel thrust-fault flats to the south (right). Photograph: July 2000.

\section{Stensnæes Section}

The Stensnæs Section is named after Stensnæs, which is a minor point (Danish: sten = stone; næs (pynt) = point) at a gentle bend in the cliff section. Stones and erratic blocks, probably derived from the up to $2 \mathrm{~m}$ thick sandy till and the erosional unconformity below the Vendsyssel Formation, were formerly abundant on this part of the beach. The sandy till thins out southwards where a glaciotectonic unconformity truncates the section.

The Stensnæs Section displays the most spectacular folds in the Rubjerg Knude Glaciotectonic Complex (Fig. 53). The folds are situated at the transition from the flat-lying beds to the south (the Ulstrup Section) and the main thrust-fault imbrications to the north. The fold complex is truncated by an erosional unconformity forming a depression in which slump slides and sedimentary breccias derived from the tip of the thrust sheet were deposited after collapse and gravity gliding. In general, the fold complex is well exposed, whereas the transition further southwands is often covered by sand scree. During the years of study of the Rubjerg Knude Glaciotectonic Complex by the author, variations in the degree of exposure of the Stensnæs Section have contributed to a fuller under- standing of the structural development of the section that represents the foreland margin of the thrust-fault complex.

\section{Tectonic architecture}

The Stensnæs Section comprises four thrust sheets (SN01, SN02, SN03 and SN04, Plate 2). The southern boundary of the section is defined by the footwall ramp of UL02, although the trailing end of UL02 is here included in the description of the imbricate duplex that hosts the fold complex. The northern boundary is the hanging-wall ramp of MB01/MB02, that is thrust up along the footwall block of SN04. The thrust sheets comprise the uppermost part of the Lønstrup Klint Formation and a relatively thin cover of the overlying Rubjerg Knude Formation sediments. Two discrete piggyback basins (early and late) were formed above the SN01 and SN02 thrust sheets.

The SN01 thrust sheet is about $30 \mathrm{~m}$ thick, and although the thrust sheet includes a number of small duplex imbricates it can be subdivided into upper and lower segments. The lower segment is thrust onto the UL02 fo otwall block with a displacement of fabout30 m. The displacement of the upper segment is partitioned 
Fig. 54. Ball-and-pillow structures in the Lønstrup Klint Formation in the Stensnæs Section. Note that the size of the structures reflects the thickness of the sand beds involved. Photograph: July 2000; staff divisions are $20 \mathrm{~cm}$.
Fig. 55. Dish-and-pillar structures developed in the lowermost sandy bed above the hanging-wall flat of the SN2 thrust sheet in the Stensnæs Section. This type of water-escape structure is interpreted to have formed during the thrust-fault translation along a hangingwall flat due to the high water pressure released from the sole of the thrust sheet. Photograph: July 1998.
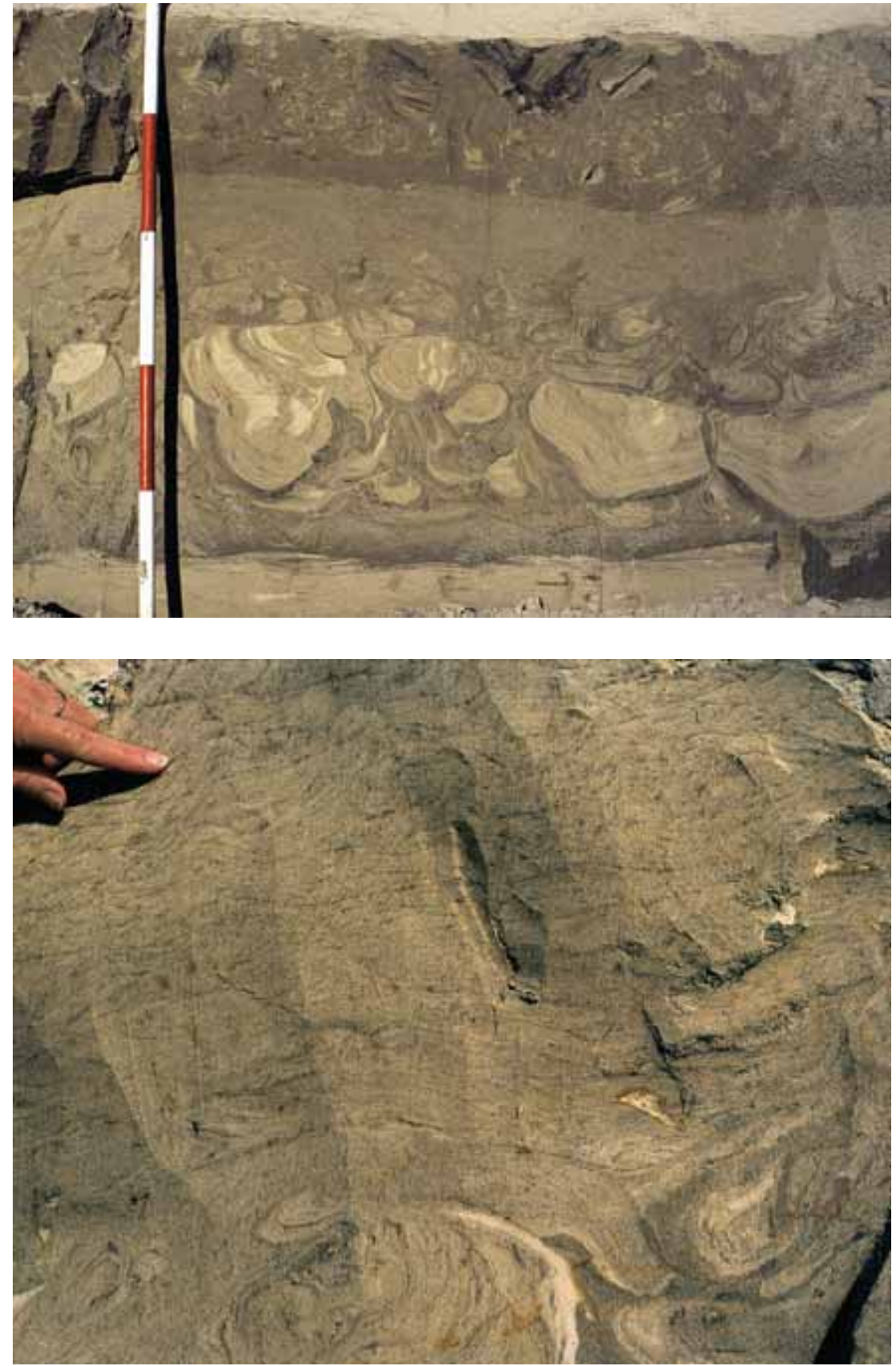

into a series of minor differential displacements ranging from minor flexural slips along bedding surfaces in the fold structures to imbricate offsets of about 1-3 m.

In the frontal part of the SNO2 thrust sheet, the Lønstrup Klint Formation is only a few metres thick, and is overlain by $10 \mathrm{~m}$ of sediments of the Rubjerg Knude Formation resting on the L/R-unconformity. At the trailing end of the thrust sheet, the Lønstrup Klint Formation is more than $15 \mathrm{~m}$ thick, whereas the Rubjerg Knude Formation is cut off by the footwall ramp of SNO2 (corresponding to the hanging-wall thrust fault for the imbricates of SN03). The accumulated displacement of SN02 amounts to $88 \mathrm{~m}$, including $15 \mathrm{~m}$ up over the footwall ramp and $73 \mathrm{~m}$ along the footwall flat of SN01.

The SN03 thrust sheet may be divided into four imbricate segments thrust onto the footwall ramp of SN02. The displacement along the hanging-wall thrust fault is $45 \mathrm{~m}$, but it was also carried piggyback on SN02 during the translation along the décollement zone, which gives an accumulated displacement of $163 \mathrm{~m}$ for the SN03 thrust sheet. 


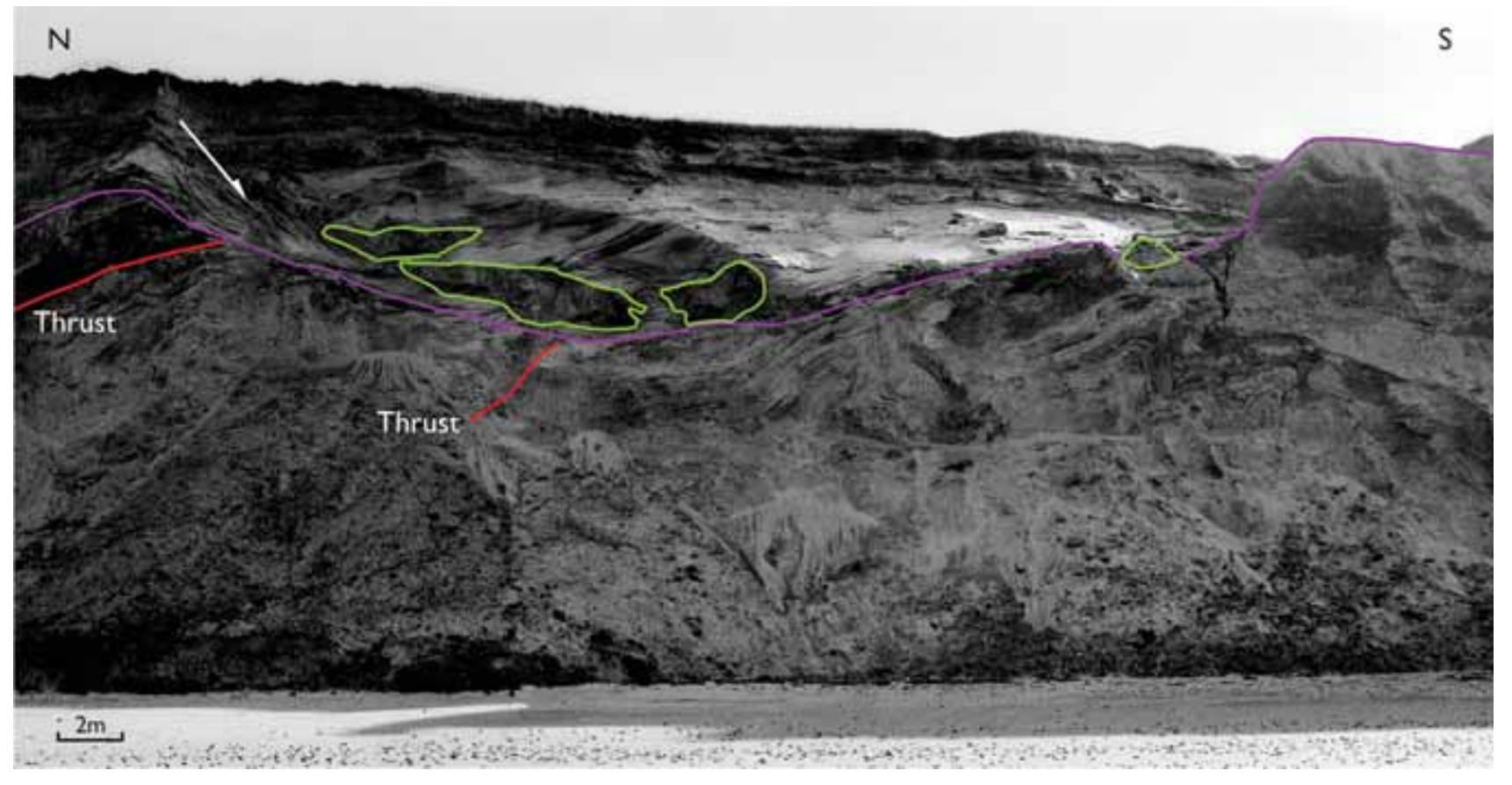

Fig. 56. The piggyback basin situated above the erosional truncation of thrust sheet UL02 and SN01 in the Stensnæs Section (SNstRu in Plate 2). Note that normal listric faults (arrow) may be traced to the trailing end of the large olistoliths (green) deposited in the meltwater sand and gravel. This is interpreted as the result of gravity gliding of the tip of a thrust sheet, which during propagation from the north collapsed subsequent to thrust faulting up above the mean level of sedimentation. Photograph: July 2000; thrusts indicated in red, unconformity indicated in purple.

The SN04 thrust sheet is about $20 \mathrm{~m}$ thick, including an up to $8 \mathrm{~m}$ thick unit of the Rubjerg Knude Formation resting on the L/R-unconformity above the Lønstrup Klint Formation; this unit increases in thickness to about $15 \mathrm{~m}$ towards the trailing end of SN04. Total displacement is about $45 \mathrm{~m}$, including a hanging-wall ramp-and-flat propagation along the footwall ramp of SN03.

\section{Sedimentary units}

The sedimentary units that crop out in the Stensnæs Section are dominated by the upper sandy parts of the Lønstrup Klint Formation. A lens of a glaciolacustrine diamictite is preserved as an imbricate thrust sheet, c. $3.5 \mathrm{~m}$ thick and $22 \mathrm{~m}$ long, and is tentatively interpreted to form part of the Rubjerg Knude Formation. The latter is mainly represented by a 6-8 $\mathrm{m}$ thick succession including the residual gravel deposited on the uneven surface of the L/R-unconformity. An upper unconformity truncates the SN01 and SN02 thrust sheets, and coarse gravel beds as well as olistoliths of the Lønstrup Klint Formation were deposited in a late piggyback basin (SnstRu in Plate 2).

\section{Lønstrup Klint Formation}

The sedimentology of the Lønstrup Klint Formation in the Stensnæs Section is similar to that described for the Ulstrup Section. The maximum thickness of the formation is about $15 \mathrm{~m}$, and lithologies are dominated by $0.2-0.8 \mathrm{~m}$ thick fine-grained sand beds with climbing ripple lamination. Thin laminae of mud and small amounts of detrital organic material commonly drape the ripples. The sand beds are interlayered with thin laminated dark grey mud beds; micro-faulting is evident in this facies. Ball-and-pillow and convolute structures are abundant (Fig. 54). In the uppermost $4 \mathrm{~m}$ of the formation, the sandy beds become thinner and the uppermost part is dominated by mud. In sand beds inferred to be situated above the hanging-wall flat, dish-and-pillar structures have been observed (Fig. 55) that are interpreted to have formed by waterescape processes related to the thrusting.

Cheel \& Rust (1986) provided a model for the development of water-escape structures in glacial outwash deposits from Ottawa, Canada. In their model, a sequential development from simple load structures through detached ball-and-pillow structures to dish structures is demonstrated. The model predicts a stra- 
tified distribution with convolute stratification at the base of a bed, ball-and-pillow structures dominating the main part, and dish structures formed in the uppermost part of the bed (or unit) resulting from excess pore-water fluid pressure. The observed waterescape structures in the Stensnæs Section as well as in the sections further to the north compare well with the model of Cheel \& Rust (1986) (Figs 54, 55; see also Fig. 77), although they suggested the triggering mechanism to be earthquakes or movements due to melting of dead-ice.

\section{Rubjerg Knude Formation}

In the Stensnæs Section, two units of the Rubjerg Knude Formation are distinguished: (1) a lower unit dominated by fine- to medium-grained glaciofluvial sand, and (2) an upper unit of varied sedimentary breccias and coarse-grained clastic deposits that infills the piggyback basin on top of the truncated thrust sheets in the section (Fig. 56). The sand deposited in the lower unit may be planar parallel stratified, or exhibit large-scale trough cross-bedding with shallow troughs, only $0.5 \mathrm{~m}$ deep. The lower unit of the $\mathrm{Ru}-$ bjerg Knude Formation is estimated to be $6-8 \mathrm{~m}$ thick, and although strongly affected by hydrodynamic brecciation, the unit compares well with the description of the lower part of the formation provided by Sadolin et al. (1997).

The upper unit was deposited on the erosional unconformity truncating the back of the UL02 thrust sheet, the fold and imbricate complex of SN01, and the tip of the SN02 thrust sheet (SnstRu in Plate 2). The central part of the basin is about $7 \mathrm{~m}$ thick, decreasing towards both the north and south forming a relatively narrow trough. The sediments in the basin consist of large-scale irregularly trough cross-bedded glaciofluvial sand and gravel. Blocks of sandy mud, which can be identified as derived from the Lønstrup Klint Formation, were deposited as sedimentary breccias in the basin. The clasts are up to $1 \times 5 \mathrm{~m}$ in size; blocks and clasts less than one metre in size were commonly rotated during redeposition. Nomal listric faults in the northern part of the basin relate to the deposition of the largest olistoliths (Fig. 56). The southern part of the basin was tilted subsequent to deposition due to the fault-bend folding of the hanging-wall flat of UL02 when it propagated along the footwall flat during the latest phase of thrust faulting. Thus the upper unit of the Rubjerg Knude Formation in the
Stensnæs Section is interpreted to have been deposited in a piggyback basin in which thrust-sheet tips thrust up from the north collapsed and gravity-glided out into the basin.

\section{Structures}

Two types of structures in the Stensnæs Section are related to thrust faulting: (1) the folding related to duplex imbricates, and (2) extensional faults related to push-from-the-rearin the trailing end of a thrust sheet.

\section{Imbricate duplex folding}

The folds in the Stensnæs Section can be described as flexural slip folds, and have amplitudes of 1-3 $\mathrm{m}$ and wavelengths of 2-5 m (Figs 53, 57, 58). The folds are very irregular in shape, however, and cannot be explained in terms of simple compression. Analysis of the flexural slip surfaces shows that the folded layers were separated into segments and that discordant relationships exist between beds in neighbouring segments. By defining the segments as small imbricate thrust sheets in a duplex, thrust-fault terminology can be applied and hanging-wall and footwall thrusts of the individual duplex segments defined. In Fig. 57 this has been done by identifying the footwall ramps (FWR), thus distinguishing five imbricate thrust sheets about $1 \mathrm{~m}$ in thickness. The folds in the imbricate duplex segments include both hanging-wall anticlines and footwall synclines. As documented by the refolding of the upper hanging-wall anticline in Fig. 57, the folds are superimposed by sequential phases of folding and thus also phases of imbricate thrusting. Figures 58 and 59 illustrate the sequential development of imbricate thrusting; the imbrication steps forward towards the footwall ramp of UL02 to the south. Note also that the hanging-wall flat of each imbricate continues into an intraformational bedding-parallel thrust fault. This can be difficult to recognise in an isolated exposure, where the flats cannot be traced back to the ramp structures in the imbricate duplex (Fig. 53).

\section{Extensional faults}

In the trailing part of the SN03 thrust sheet, listric extensional faults have been observed (Fig. 60). Displacements along the faults are up to $0.5 \mathrm{~m}$ and the 

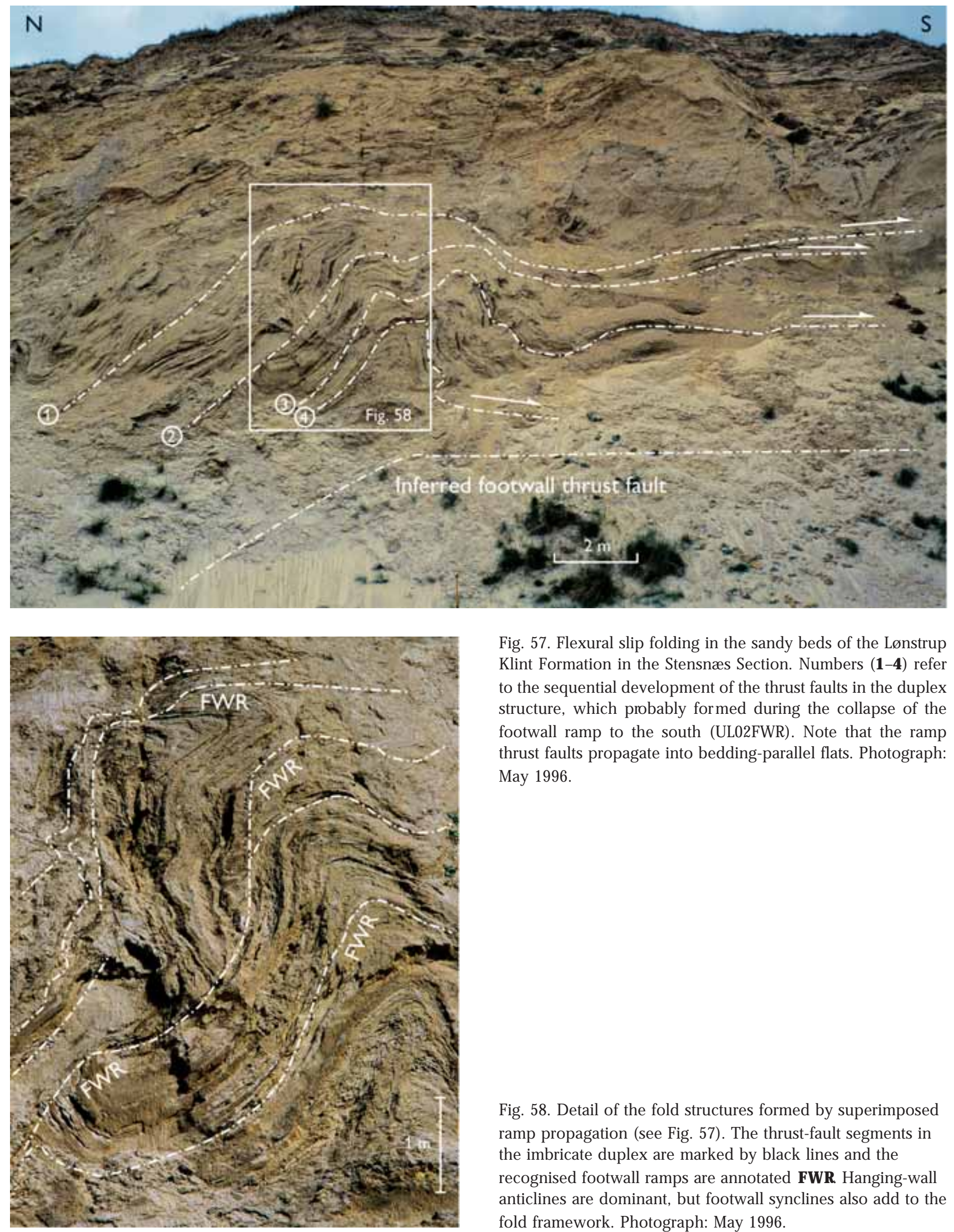

Fig. 57. Flexural slip folding in the sandy beds of the Lønstrup Klint Formation in the Stensnæs Section. Numbers (1-4) refer to the sequential development of the thrust faults in the duplex structure, which probably formed during the collapse of the footwall ramp to the south (UL02FWR). Note that the ramp thrust faults propagate into bedding-parallel flats. Photograph: May 1996.

Fig. 58. Detail of the fold structures formed by superimposed ramp propagation (see Fig. 57). The thrust-fault segments in the imbricate duplex are marked by black lines and the recognised footwall ramps are annotated FWR Hanging-wall anticlines are dominant, but footwall synclines also add to the fold framework. Photograph: May 1996. 


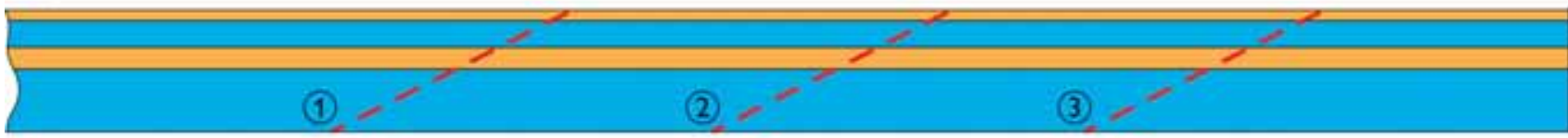
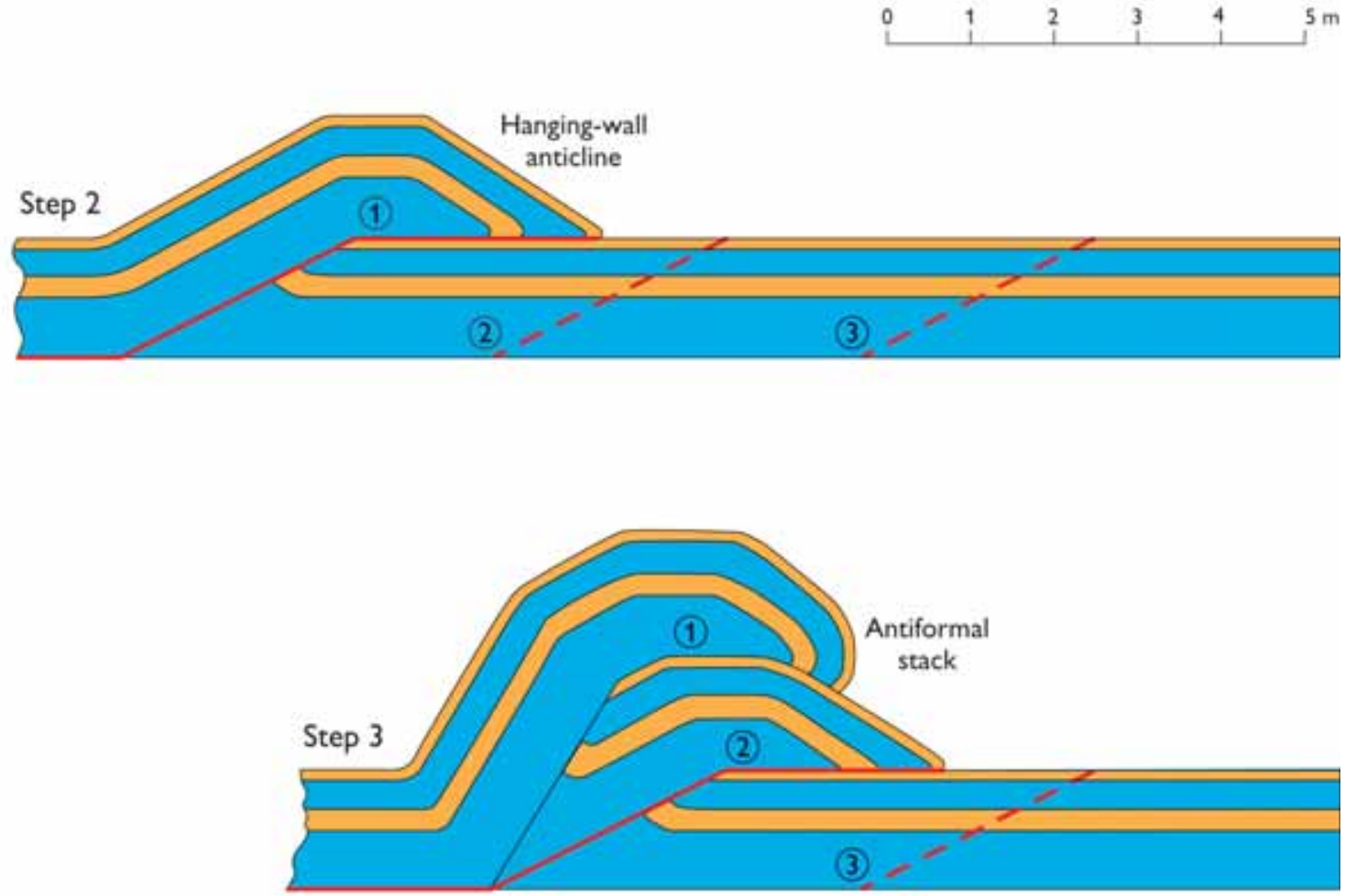

Clayey mud

Fine sand

Thrust fault

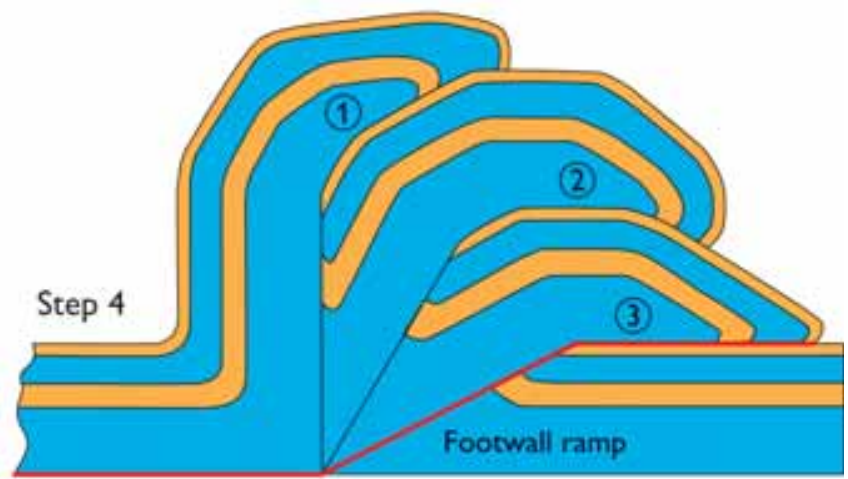

Fig. 59. Simplified model of superimposed folding formed by sequential imbrication in a duplex complex. Step 1 shows the undeformed beds with the ramps bordering the segments indicated. The numbers refer to the sequentially propagating hangingwall ramps. Step 2 shows the first hanging-wall anticline to be formed by the progressive collapse of the trailing end of the footwall block (footwall ramp collapse). Step 3 illustrates the formation of an antiformal stack during the progressive superimposed deformation. Step 4 demonstrates the developed stage of superimposed fault-bend folding comparable to the structures illustrated in Figs $57,58$. 



Fig. 60. Low-angle listric extensional faults in the SN03 thrust sheet, in the central part of the Stensnæs Complex. A: An overview of the macroscopic structure, where the SN04 thrust sheet ramps up along the footwall flat of SN03 and pushes it laterally in the back. The resultant extensional fault imbricates form a boudinage-like network. B: Detail of the listric extensional faults (arrows) interpreted to have been formed by push-from-the-rear. Photograph: July 1996; staff divisions are $20 \mathrm{~cm}$. 


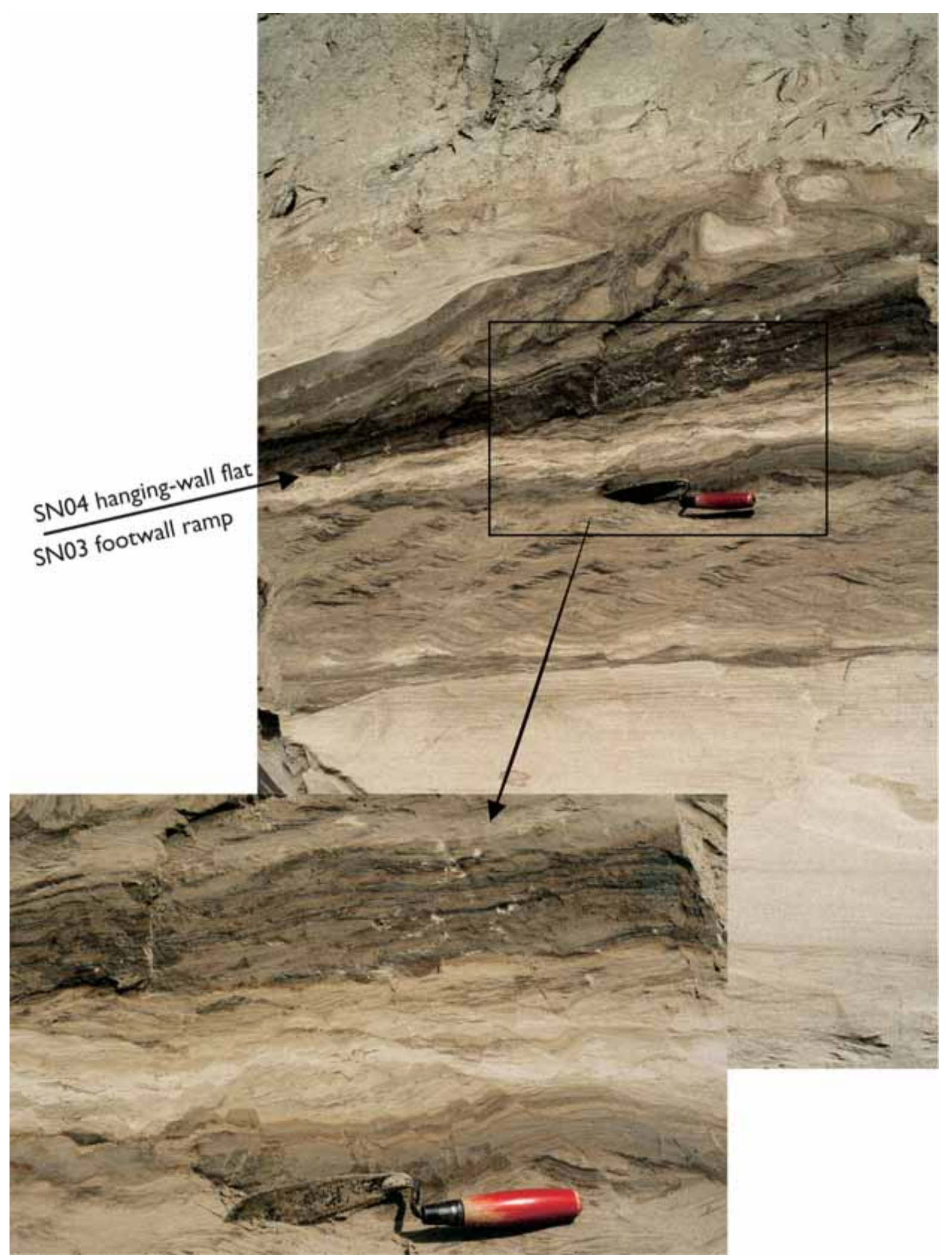

Fig. 61. Illustration of the difference between the mild deformation affecting the top of the footwall block and the strong deformation of the hanging-wall block. Only a $20 \mathrm{~cm}$ thick zone below the shear-laminated thrust-fault surface was affected by low-angle extensional faulting grading down into a minor normal fault network. It is thus evident that the elevated water pressures supporting the thrust sheet were transmitted to the hanging-wall flat, where intense hydrodynamic brecciation took place. Photograph: July 1998. 
spacing between the faults is $0.2-0.6 \mathrm{~m}$, which creates a boudinage-like network. The structures are interpreted to have been formed by push and loading of a thrust sheet ramping the formerly monoclinal fault-bend-folded thrust sheet, which responded to the gravity spreading by displacements along the extensional faults.

Similar mini-scale extensional normal faults are recognised in the footwall block below the hanging-wall flat of SN03 (Fig. 61). It is remarkable that the thrustfault deformation only weakly affects the top of the footwall block, while the hanging-wall block is strongly affected by hydrodynamic brecciation. A zone only $20 \mathrm{~cm}$ thick below the shear-laminated thrust-fault surface is affected by low-angle extensional faulting, and grades down into a minor normal fault network (Fig. 61). Isoclinal folding has been observed in the narrow shear-laminated thrust-fault zone, adding to the impression of high strain along the thrust fault. However, it is clear that the elevated water pressures supporting the thrust sheet were located in the hanging-wall flat.

\section{Interpr etation of structural development}

The formation of the imbricate duplex fold complex in the Stensnæs Section is evidently related to ramp propagation. Two footwall ramps are significant: the footwall ramp of UL01, which can be regarded as representing the footwall ramp of the foreland, and the footwall ramp of the trailing end of UL02. The UL01 footwall ramp acted as a stopping block for the forward push of the imbricate thrust sheets, and the propagation of this ramp was responsible for the general gentle northerly tilt of the structures. The UL02 footwall ramp was subjected to successive thrust-fault splay formation, and consequently imbrication and superimposed folding, which can be viewed as the collapse of the trailing end of the UL02 thrust sheet.

The imbricate duplex fold complex of the Stensnæs Section can be readily compared to the model for connecting splay duplexes of the Sevier thrust belt in the Cordilleran Fold Belt (Mitra \& Sussmann 1997). There is a close similarity with respect to the growth of the duplex by successive connecting splays of the thrust fault and the creation of folds by thrust-fault propagation. Moreover, the analysis of the imbricate duplex fold complex implies that the imbrication started at the footwall ramp in the trailing end of the system and propagated towards the foreland. It can therefore be argued that the process was one of footwall ramp collapse. A simplified model for the growth of duplexes in a connecting splay duplex system is illustrated in Fig. 59.

With respect to the thrust-fault displacement, an active and a passive stage of translation need to be distinguished.The active translation is the amount of displacement of the thrust sheet arising from propagation along its hanging-wall thrust fault. The passive translation is the amount of transport arising from the displacement of the underlying thrust sheet which carries it piggyback fashion. During this latter translation, the underlying thrust sheet may propagate footwall ramps, which will fold the actively translating thrust sheet as well as the piggyback thrust sheets into hanging-wall anticlines. This type of deformation will create an antiformal stack. The Stensnæs imbricate duplex fold complex may thus also be viewed as a mesoto macroscopic-scale antiformal stack (Fig. 59).

A roof thrust, which is $110 \mathrm{~m}$ long and about 8-12 $\mathrm{m}$ thick covers the SN01-SN02 duplex. The accumulated length of the three duplex segments is $175 \mathrm{~m}$; c. $65 \mathrm{~m}$ is thus missing in the balance calculation of the southern half of the Stensnæs Section. It is most likely that part of the initial thrust sheet has been eroded away, but up to c. $45 \mathrm{~m}$ of it might have been incorporated in a foreland-dipping frontal thrust structure preserved in the chaotic imbricate fold complex.

\section{Martørv Bakker Section}

The name Martørv Bakker is derived from the peat exposed in the coastal cliff (Danish: $\mathrm{mar}=$ sea; tørv = peat; bakker = hills), which is covered by aeolian sand dunes above the northern end of the section. In the southern part of the section, the Vendsyssel Formation forms the top unit in the cliff. The Vendsyssel Formation was deposited on an erosional unconformity above the glaciotectonic complex. All the posttectonic deposits are prone to cliff erosion and the resultant scree partly obscures the structures in the Martørv Bakker Section. In addition, the unconformity at the base of the planar-bedded Vendsyssel Formation is a focus for groundwater seep which also conceals details in the exposures. However, two important architectural elements have been recognised: (1) the common appearance of minor duplexes in the southern part of the section, and (2) the occurrence of southerly dipping normal faults in the northern part.

The southem boundary of the section is the footwall ramp of SNO4 in the trailing end of the Stensnæs 


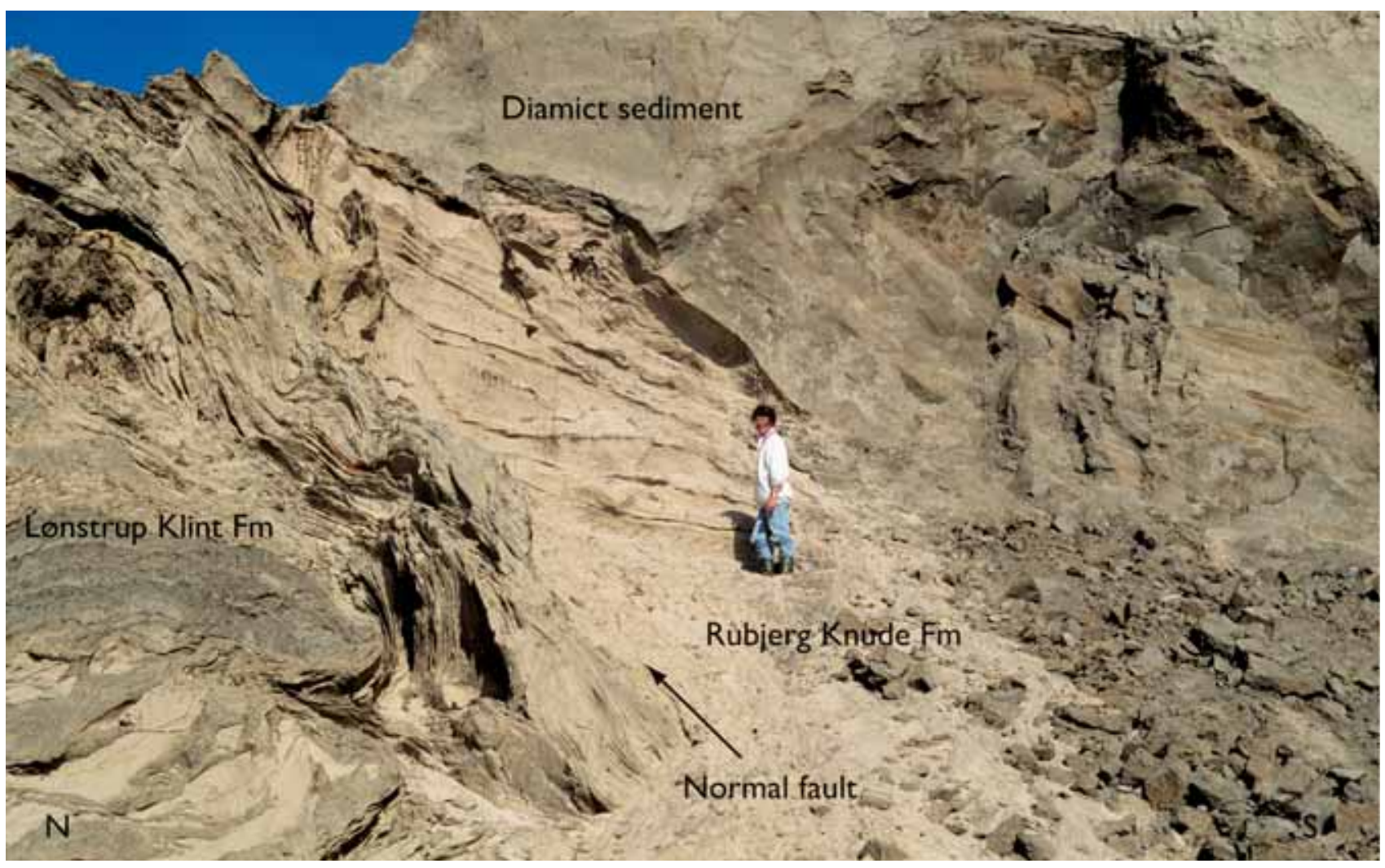

Fig. 62. The normal fault developed in the central part of the Martørv Bakker Section. In the hanging-wall block to the south, the fluvial sands of the lower part of the Rubjerg Knude Formation are preserved in a 'fault trap' along the fault plane. Diamict sediments were deposited above the sand in a piggyback basin that developed during the thrust faulting of the MB02 thrust sheet. Note that the thickness of the Lønstrup Klint Formation in the footwall block decreases downwards along the normal fault drag. This is interpreted as a foreland-dipping limb related to a hanging-wall anticline formed prior to offset by the normal faulting. The formation of the normal fault is interpreted to be related to a foreland-dipping limb of a hanging-wall anticline at the tip of a subsurface thrust-sheet segment (MB02u3 in Plate 2). Photograph: June 1993.

Section. The northem boundary is not defined by a simple reference point in the cross-section, but by the trailing end of the MB04 thrust sheet which is a combination of footwall ramp and footwall flat below the leading-edge thrust fault of the Kramrende Section.

\section{Tectonic architecture}

The Martørv Bakker Section is subdivided into four thrust sheets (MB01-MB04). The thrust sheets in the southern part of the section are subdivided into upper and lower duplex segments of which only the lower duplex segments are distinguished by separate annotations (MB02u1-MB02u3, Plate 2). In the frontal part of the section, smaller imbricate duplexes are associated with syntectonically formed hydrodynamic breccias and ball-and-pillow structures.

The MB01 thrust sheet is up to $20 \mathrm{~m}$ thick and com- prises the upper part of the Lønstrup Klint Formation. The frontal hanging-wall ramp was thrust up along the $15^{\circ}$ dipping footwall ramp of SN04, and displacement is estimated at about $55 \mathrm{~m}$. The bedding becomes steeper in the trailing end of the thrust sheet, probably due to the relatively steep dip of the ramp in the subsurface from the $20 \mathrm{~m}$ to the $10 \mathrm{~m}$ flat level.

The MB02 thrust sheet is long and flat-lying and occupies more than $400 \mathrm{~m}$ of the section. The frontal part is only $10-15 \mathrm{~m}$ thick and was displaced along its upper hanging-wall flat along the footwall flat of MB01 for a distance of about $180 \mathrm{~m}$. The trailing part of the MB02 thrust sheet is $20 \mathrm{~m}$ thick, but as indicated in the balanced cross-section it roots down to the $30 \mathrm{~m}$ décollement level (Plate 2). The thrust sheet is displaced by a prominent normal fault in the central part of the Martørv Bakker Section (Fig. 62). Above the Lønstrup Klint Formation, a marked basin developed in the hanging-wall block of the normal fault. The 

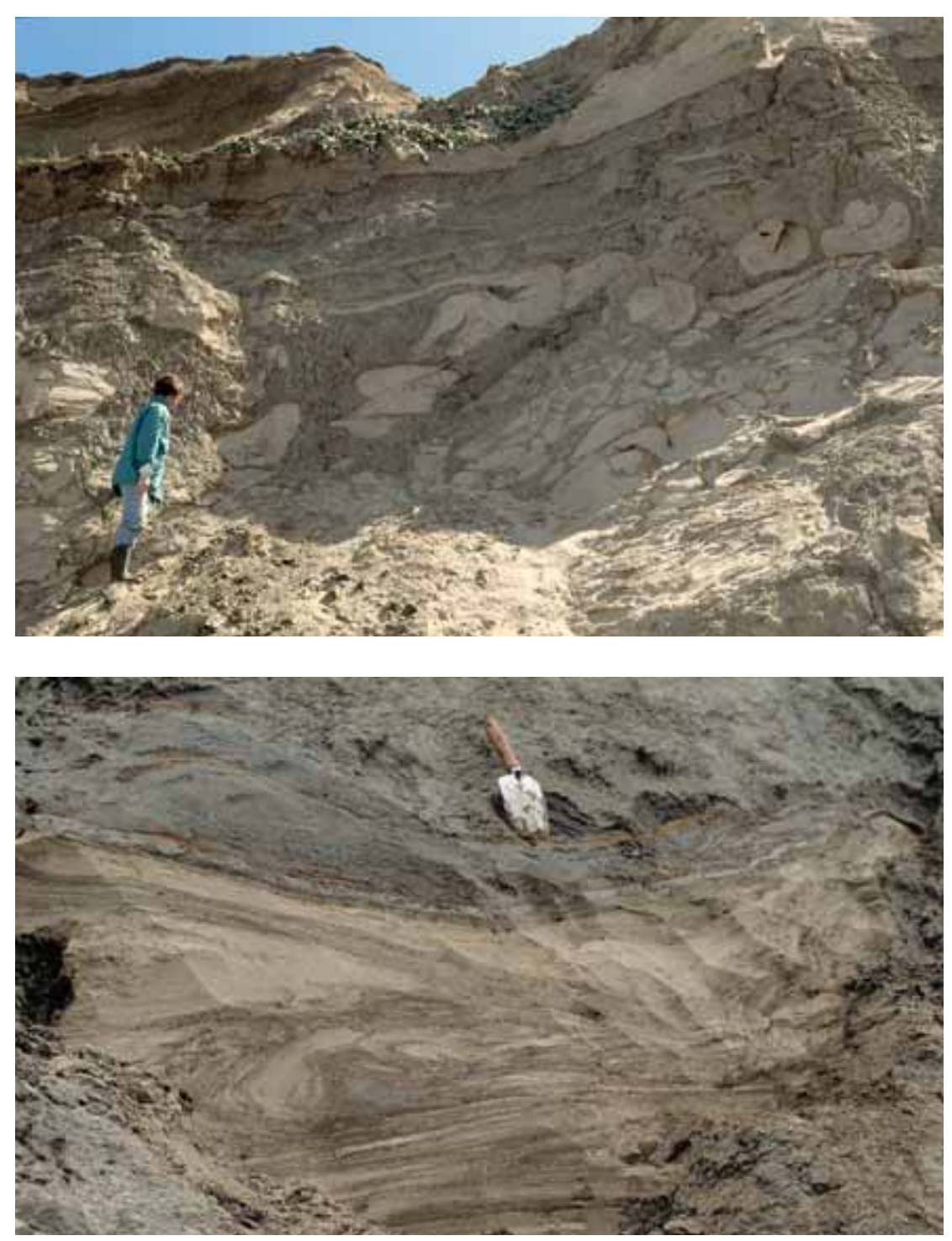

Fig. 63. Hydrodynamic brecciation in the Lønstrup Klint Formation in the northern part of the Martørv Bakker Section. Photograph: June 1993.
Fig. 64. Slump-fold structures formed in the thin-bedded sand layers enveloped in dark muds of the diamict sediments in the piggyback basin in the Martørv Bakker Section. Photograph: October 1998. sediments in this basin were described as moraine sand by Jessen $(1918,1931)$.

The MB03 thrust sheet is $30 \mathrm{~m}$ thick and made up of the Lønstrup Klint Formation, which is here strongly deformed by hydrodynamic brecciation and dislocated by a number of bedding-parallel minor thrust faults. Thefrontalpart isflat-lying, whereasthe dip of the bedding increases to $25-30^{\circ}$ at the trailing end indicating a bend over an upper hinge on top of the footwall ramp of MB02. In the exposed part of the section, the MB03 thrust sheet is only about $120 \mathrm{~m}$ long, and it is inferred that the foreland-dipping structures in the frontal part reflect re-orientation due to hanging-wall ramp propagation along the footwall flat of MB02.

The MB04 thrust sheet forms a flat-topped hanging-wall anticline above the footwall ramp of MB03.
The thrust sheet is displaced along a nomal fault parallel to the foreland-dipping bend in the top of the frontal part of MB03. The normal fault does not displace the footwall flat of MB02, and is therefore regarded as a structure related only to the framework of MB03 and MB04. The structural framework in this part of the section may be characterised as an antifomal stack, including thrust sheets MB03 below and KR01 above MB04.

\section{Sedimentary units}

The Martørv Bakker Section is dominated by the Lønstrup Klint Formation. However, the most important sedimentological feature in the section is related to 
the basin developed at the top of the hanging-wall block connected to the normal fault displacing the MB02 thrust sheet (Fig. 62). The deposits in this basin are regarded asan exotic part of the Rubjerg Knude Formation, and are described under this heading below.

The southern part of the Martørv Bakker Section is unconformably overlain by the Vendsyssel Formation, the initially glaciotectonic truncation being superimposed by a post-glacial erosional unconformity. A Holocene erosional unconformity truncates the Vendsyssel Formation as well as the glaciotectonic unconformity, and the peat deposited on this unconformity is up to $2 \mathrm{~m}$ thick in the northem part of the section, where it iscovered by modern aeolian dunes up to $20 \mathrm{~m}$ high.

\section{Lønstrup Klint Formation}

The lower part of the Lønstrup Klint Formation is mudrich. It is exposed in the northem part of the section, where it was thrust above the hanging-wall flat from the décollement surface $25-28 \mathrm{~m}$ below sea level. The upper part of the formation is dominated by $0.5-1.5$ $\mathrm{m}$ thick sand beds interlayered with thin beds of horizontally laminated mud, which typically has been mobilised to form hydrodynamic breccias. In the southern part of the section, the beds are strongly affected by ball-and-pillow deformation (Fig. 63).

\section{Rubjerg Knude Formation}

The Rubjerg Knude Formation comprises two units: (1) a lower $3 \mathrm{~m}$ thick sand unit only exposed along the prominent normal fault in the central part of the Martørv Bakker Section, and (2) a c. 15 m thick diamictite interpreted as a glaciolacustrine mud with redeposited clasts. The first unit was deposited on the L/R-unconformity, and comprises light yellowish medium-grained sand (Fig. 26). The diamictite unit rests partly on the lower sand unit, and partly on the L/Runconformity at the top of the Lønstrup Klint Formation. The diamictite is dark grey, and comprises weakly laminated mud interbedded with structureless, irregularly distributed matrix-supported beds containing
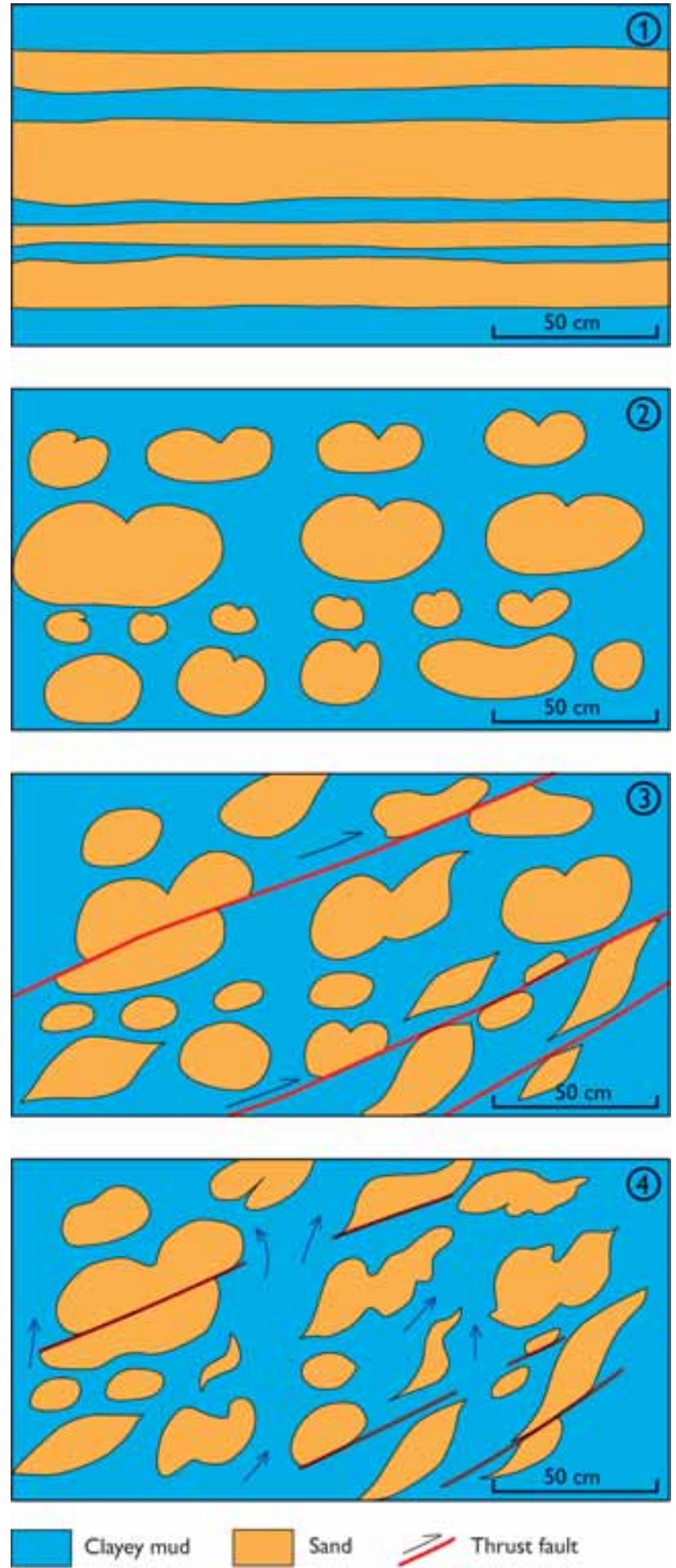

7 Direction of intrusive mud flow

Fig. 65. A schematic diagram explaining the development of the hydrodynamic brecciation displayed in Fig. 63. The formation of the structure was the result of three phases of deformation. In the first phase, a succession of sandy turbidites interbedded with mud (1) was affected by loading to form the ball-and-pillow structures (2). In the second phase, the ball-and-pillow structures were displaced by thrust faulting (3). During the third phase, the mobilised mud intruded up thorough the thrust-fault surface (4), demonstrating the syntectonic development of the hydrodynamic brecciation. 
unsorted clasts in a matrix of sandy mud (Fig. 26). In the lowermost $2 \mathrm{~m}$ of the diamictite succession, the matrix-supported clasts were probably derived by redeposition of coarse-grained material eroded from the L/R-unconformity to the north. About $3 \mathrm{~m}$ up in the succession, a c. $1 \mathrm{~m}$ thick bed occurs with clay clasts $10 \mathrm{~cm}$ in size deposited in a weakly clay-laminated and sand-streaked silty mud. This bed is overlain by three 1.5-3 m thick units of isoclinally slump-folded, thin-bedded, fine-grained sand encased in dark structureless mud (Fig. 26). These units are interpreted as slump-folded sheets derived from the Lønstrup Klint Formation (Fig. 64). The middle and upper slump-units are separated by a c. $5 \mathrm{~m}$ thick interval dominated by sandy mud with scattered clasts and a few thin sand beds. The uppermost sand bed was not affected by slumping and shows large-scale trough cross-bedding.

The lower part of the diamictite succession is strongly disturbed by hydrodynamic brecciation with mesoscopic-scale diapirs rising from the top of the Lønstrup Klint Formation and penetrating upwards into the diamict sediments. This indicates that the diamictites were part of the main sedimentation affected by glaciotectonic disturbances.

\section{Structures}

In the Martørv Bakker Section, three types of structural elements were studied: (1) imbricate duplexes dominating the southern part of the section, (2) the normal fault in the central part of the section, and 3) hydrodynamic brecciation contemporaneous with, or superimposed on, ball-and-pillow structures (Figs 63, 65).

\section{Imbricate duplexes}

The imbricate duplexes in the southern part of the section constitute rhomb-shaped segments 10 to $25 \mathrm{~m}$ in size bounded by low-angle thrust faults. Minor imbricates may occur along the thrust faults, but the thrust faults are mainly narrow fracture surfaces without significant brecciation.

A mini-scale example of duplex fomation is shown in Fig. 66. Although the structure is related to intraformational deformation of the beds, it illustrates instructively the formation of hanging-wall ramp propagation of a stacked footwall ramp. Thus the footwall ramp is formed by the trailing edges of two duplex segments that were displaced one over the other to form a single planar ramp for the propagation of the upper thrust sheet. Flame-like upright minor anticlines are interpreted as compressed hanging-wall anticlines formed during the sequential propagation of the various ramps. On top ofthe upper footwall hinge, a radial flame structure probably indicates the site of incipient diapirism (Fig. 66). The formation of foreland-dipping thrust structures above the tip of a lower duplex segment is also apparent.

\section{N ormal fault}

The normal fault in the central part of the section is an uneven fault plane striking E-W with a dip of about $45^{\circ}$ to the south. Displacement along the fault plane is about $25 \mathrm{~m}$, and a set of minor normal listric faults displace the top of the hanging-wall block (Fig. 62). The footwall block comprises the Lønstrup Klint Formation, which decreases in thickness southwards and forms an irregularly folded drag along the fault plane. At the top of the hanging-wall block, the diamict sediments described above are discordantly superposed on the light-coloured sand at the base of the Rubjerg Knude Formation.

\section{Hydrodynamic brecciation}

Ball-and-pillow structures occur in the sand-rich parts of the Lønstrup Klint Formation, where hydrodynamic mud mobilisation created chaotic breccias (Fig. 63). The initial size of the sand ball-and-pillow structures is related to the primary thickness of the beds, but subsequent to the sedimentary load deformation they were distorted and deformed during thrust-fault related mud remobilisation. In Fig. 63, the distorted ball-andpillow structures can beseen to be displaced by minor thrust faults, and these thrust faults were intruded by mobilised mud. The sequential development of this hydrodynamic brecciation is illustrated in Fig. 65, where three phases of defomation are recognised, although these probably developed progressively during thrust-fault displacement and related loading of superposed thrust sheets.

\section{Interpretation of structural development}

The thickness of MB01 implies that the décollement surface in the southern part of the section is situated 




Fig. 66. A model of duplex formation is here illustrated by a mini-scale structure related to intraformational deformation of beds in the Lønstrup Klint Formation, central part of Martørv Bakker Section. The duplex comprises two segments, which were derived from the bed underlying the lower footwall flat (lower FWF). The footwall ramp for the segments is situated to the left outside the frame of the figure. The lower segment is a relatively short one, which was thrust over by the upper segment during the push from the ramping of the upper thrust sheet. During propagation up the footwall ramp, the trailing edges of the two segments were displaced to form one planar ramp for the upper thrust sheet, which was further translated over the duplex to a foreland-dipping bend created above the tip of the lower duplex segment. The flame-like upright anticlines are interpreted as compressed hanging-wall anticlines formed during the sequential propagation of the various ramps. Note the radial flame structures at the upper footwall hinge indicating incipient diapirism. The small normal faults to the left of the trowel ( $15 \mathrm{~cm}$ in size) are thought to reflect similar forelanddipping features in the subsurface. FWH, footwall hinge; FWR, footwall ramp; $\mathbf{~ F W F , ~ u p p e r ~ f o o t w a l l ~ f l a t ; ~ H W F , ~ h a n g i n g - w a l l ~ f l a t ; ~} \mathbf{R}$, ramp. Photograph: June 1993.

at the $20 \mathrm{~m}$ level. The thickness of MB03 is $30 \mathrm{~m}$, implying that the décollement level stepped down 10 $\mathrm{m}$ somewhere in the central part of the section. A lower footwall ramp and a corresponding hangingwall ramp must therefore be included in the balanced cross-section. The L/R-unconformity reference surface on top of the MB02 thrust sheet was about $20 \mathrm{~m}$ above present sea level prior to the normal fault displacement, which indicates that a duplex $20 \mathrm{~m}$ in thickness is situated below the trailing end of MB02. The lower footwall ramp responsible for the fault-propagation folding of the antiformal stack in the northem part of the section, estimated from the bend of the trailing ends of MB02 and MB03, must be situated below MB02. The structural model therefore suggests that a subsurface duplex was formed by segments of the MB02 thrust sheet situated between the 20 and $30 \mathrm{~m}$ levels (MB02u1-MB02u3). The footwall ramp thus constitutes two $10 \mathrm{~m}$ thick duplex segments stacked on top of each other.

Consequently, a hanging-wall anticline with a foreland-dipping limb formed above the hanging-wall ramp of MB02 and was translated along a footwall flat. The model further suggests that the hanging-wall 


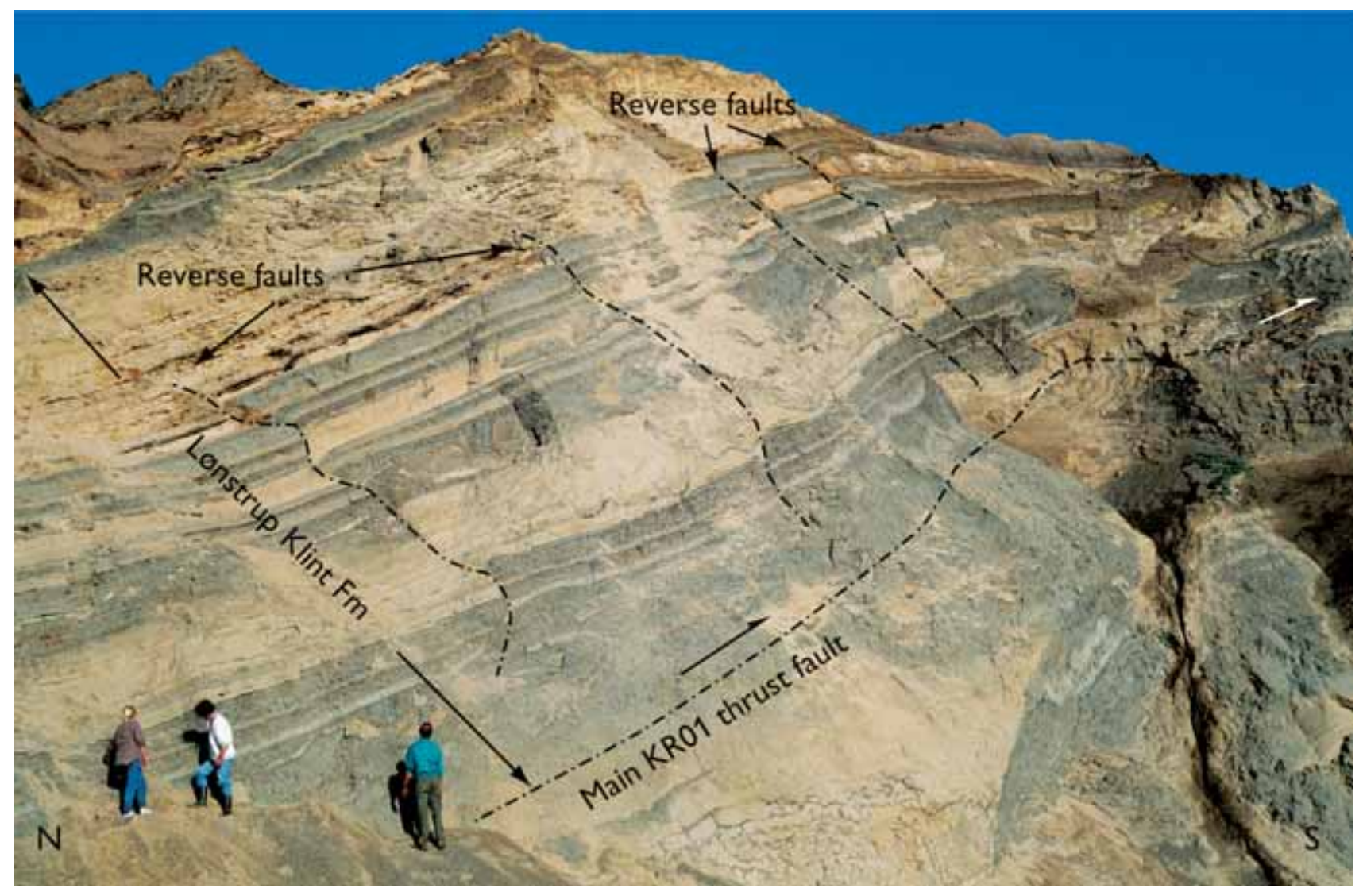

Fig. 67. The northern part of the KR01 thrust sheet where the lithostratigraphic reference section of the Lønstrup Klint Formation (Fig. 21) is situated. The thrust sheet is fault-bend-folded up along an initially low-angle (c. $8^{\circ}$ ) footwall ramp, which was subsequently folded into the present more steeply dipping orientation. Note the reverse faults interpreted as small back-thrust faults. Photograph: June 1993.

structure is a composite feature partly constructed by the hanging-wall anticline related to the tip of the MB02u3 segment folded over the footwall ramp of MB02u2, and partly by the hanging-wall anticline related to the translation of the main hanging-wall ramp of MB02 along the $10 \mathrm{~m}$ level. The foreland-dipping limb of this structure corresponds well with a $45^{\circ}$ south-dipping normal fault with a vertical displacement of about $20 \mathrm{~m}$.

It is therefore concluded that the northern slope of the diamict sedimentary basin was formed by the normal fault reflecting the foreland-dipping limb of a hanging-wall anticline. The southern more gently dipping slope of the basin was formed by the bend of MB02 due to its propagation up along the footwall ramp and flat of MB01. This footwall thrust fault is a composite imbricate duplex, which hampers the exact distinction of ramp-flat relationships. The slumpfolded units in the basin are interpreted as the result of gravity slides derived from the crest of the hang- ing-wall anticline or the tip of the MB04 thrust sheet propagating from the north. The sediments filling the basin represent redeposited material derived from the thrust-fault elevated part of the Lønstrup Klint Formation, the coarse-grained clastics on the L/R-unconformity, and the lowermost part of the Rubjerg Knude Formation. The basin is interpreted as a piggyback basin with syntectonic deposition during the translation of the MB02 thrust sheet.

\section{Kramrende Section}

From the south, the first significant macroscopic-scale diapir occurs in the Kramrende Section (the Kramrende diapir). Although mobilisation features also occur in sections farther to the south, this diapir is regarded as the most distal in the glaciotectonic thrustfault complex. The thickness of the thrust sheet hosting the Kramrende diapir suggests it is related to the 
Fig. 68. Ball-and-pillow structure developed in the sandy turbidite bed between 4 and $5 \mathrm{~m}$ in Fig. 21. The structure is interpreted as a load structure formed immediately after sedimentation. Additional load structures can be seen at the base of the sand bed, where flame structures related to the underlying clayey bed intrude the base of the sand bed. Above the balland-pillow structure, pinch and swell structures within the sand bed are also interpreted as gravity load structures. Photograph: June 1993.

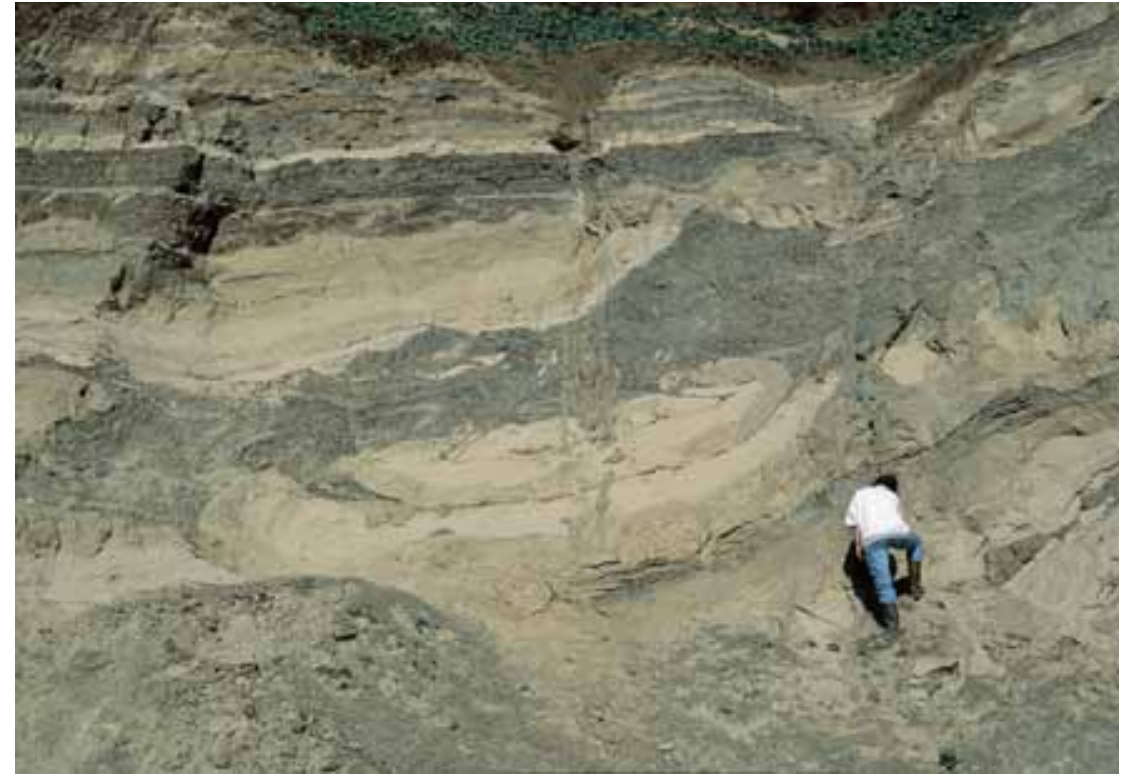

Fig. 69. In the upper part of the KR04 thrust sheet in the Kramrende Section, the Rubjerg Knude Formation forms a piggyback basin, which is overthrust by the BR01 thrust sheet in the southern part of the Brede Rende Section. The thrust fault displayed in the photograph is a hanging-wall flat for the thrust sheet BR01 (BR01HWF) and footwall ramp of thrust sheet KR04 (KR04FWR). A minor satellite thrust fault was formed below the main thrust at a late stage of fault propagation after the sand of the Rubjerg Knude Formation had been somewhat compacted. Photograph: June 1984.

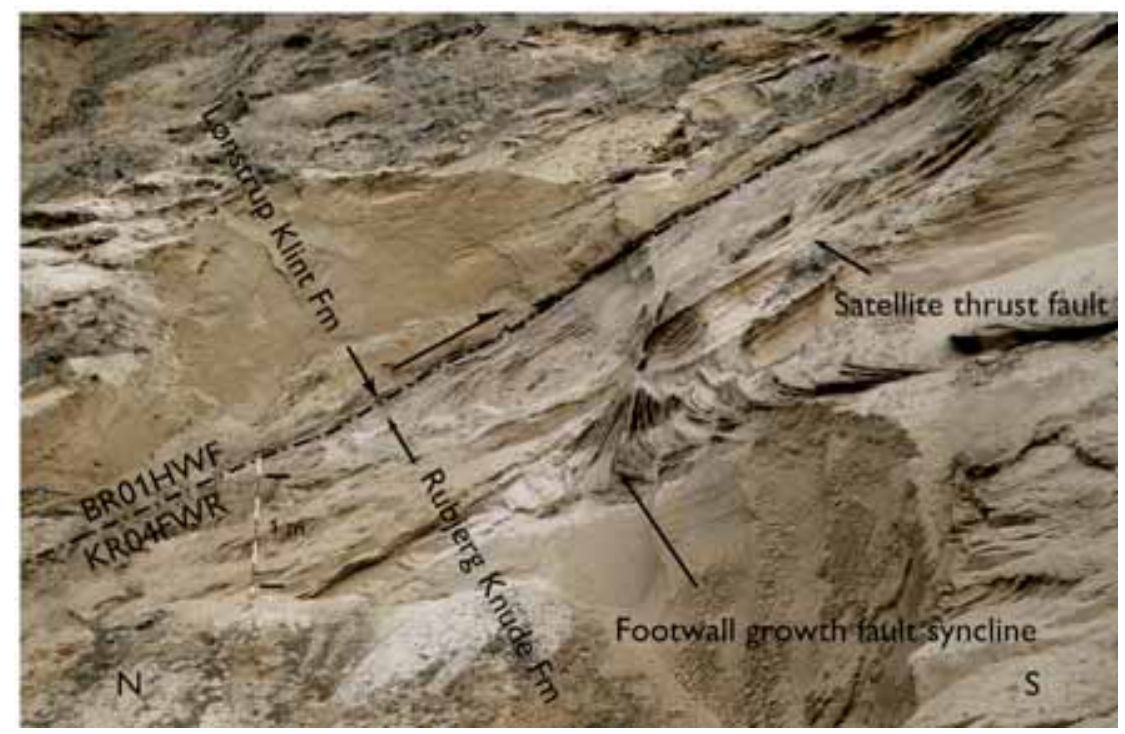

deep level of thrust-fault rooting, which is about $30 \mathrm{~m}$ below the L/R-unconformity. The thrust sheet to the south of the Kramrende diapir and two thrust sheets to the north are included in the section because they are all affected by the structures related to the diapir. The frontal edge of the Kramrende Section is formed by the footwall ramp beneath the first thrust sheet (KR01, see Plates 1, 2). This thrust fault is identical with the trailing-edge footwall ramp of the Martørv Bakker Section, which is responsible for the marked monoclinal fault-bend folding of the KR01 thrust sheet (Fig. 67). The steps to the beach are situated in the gully between the KR01 thrust sheet and the Kramrende diapir. The steps lead up to the summerhouse area at Oddervej, and are referred to as the Kramrende steps or the Oddervej Trappe.

\section{Tectonic architecture}

The Kramrende Section consists of four thrust sheets (KR01-KR04; Plates 1, 2). The frontal thrust sheet (KR01) is ramped over the MB04 footwall ramp in the Martørv Bakker trailing thrust sheet. At the north end of KR01, the L/R-unconformity is situated about c. $10 \mathrm{~m}$ a.s.l., which indicates that the KR01 hanging-wall ramp propagated along an intermediate footwall flat (FWF). The upper ramping along the MB04 footwall ramp is 

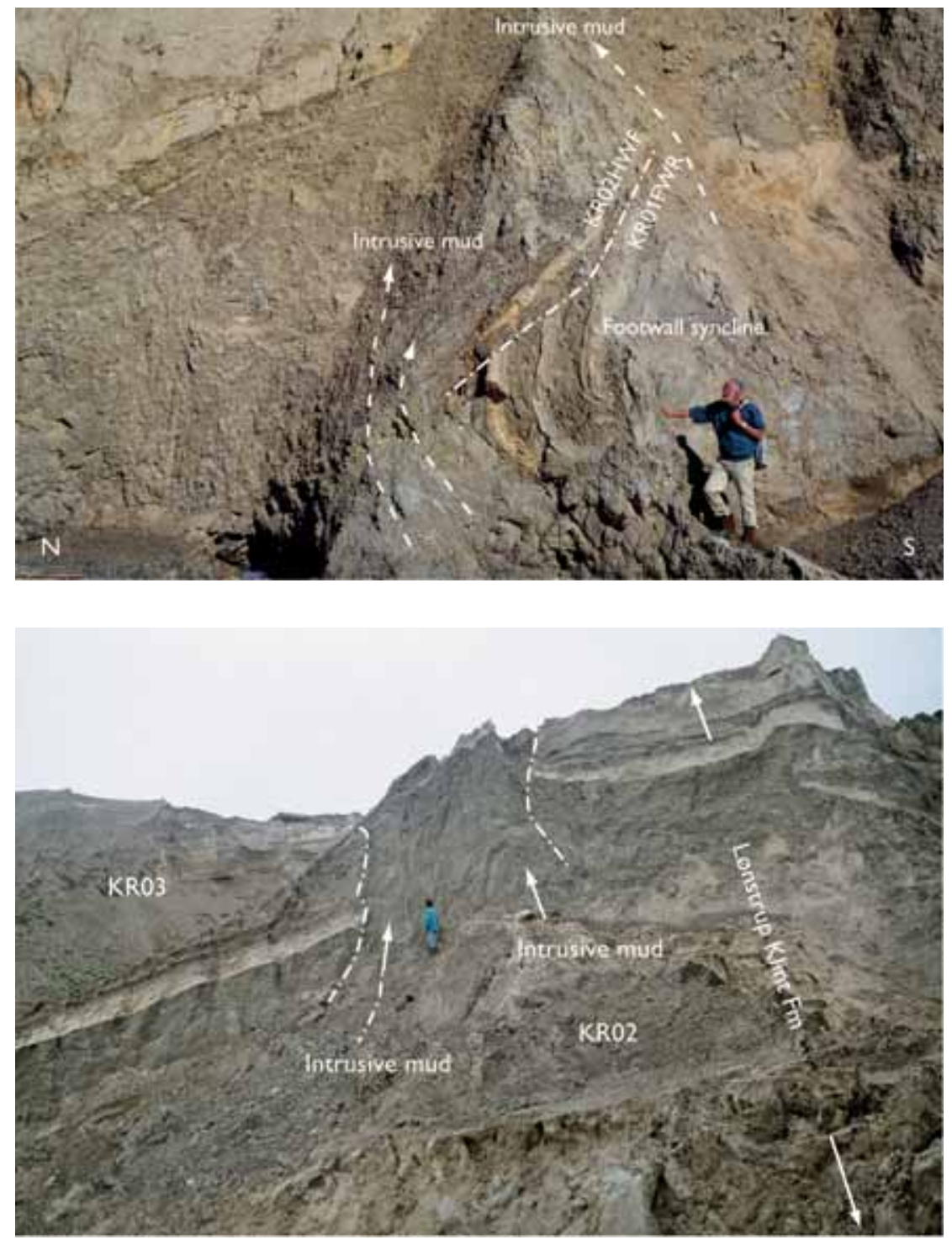

Fig. 70. The KR01 footwall syncline developed below the KR01 footwall ramp (KR01FWR), which is overlain by the KR02 hanging-wall flat (KR02HWF). Note how the mobilised mud migrated from the steeply dipping limb of the footwall syncline up into the Kramrende diapir, intrusively penetrating the thrust fault. Photograph: June 1995.
Fig. 71. Mobilised mud from the lower part of the Lønstrup Klint Fomation in the KR02 thrust sheet intruded the turbidite sand beds in the upper part of the formation. Photograph: June 1995. responsible for the fault-bend-fold appearance of the KR01 thrust sheet. Above the frontal part of the MB04 footwall ramp and flat, the KR01 thrust sheet is folded into a flat-topped anticline. In the involute part of this anticline, a splint or horse is present (the KR01 splint). This is a small thrust-sheet wedge tom off during thrust propagation, which created peculiar anticlinal features in the structural profile.

The KR02 thrust sheet takes the form of a major diapir. Initially the diapir was a thrust sheet that was displaced up along the KR01 footwall ramp and above the back of the KR01 thrust sheet. The KR03 and KR04 thrust sheets situated on the back of KR02 are characterised by marked differences in the thickness of the Rubjerg Knude Formation. In the KR03 thrust sheet, the thickness is only about $8 \mathrm{~m}$, whereas in KR04 the thickness of the Rubjerg Knude Formation is up to 20 $\mathrm{m}$. This indicates that the KR04 thrust sheet was thrust over the upper footwall flat of KR03 at an earlier stage compared to a probably longer time of deposition in the piggyback basin of KR04. The c. $20^{\circ}$ northerly dipping inclination of the KR03 footwall flat and related parallel structures is due to the bend caused by the propagation of KR02 along the footwall ramp. The main décollement level below the Kramrende Section is situated at the $30 \mathrm{~m}$ level.

\section{Sedimentary units}

The description of the sedimentary units in the Kramrende Section is mainly based on sedimentological 
logging of the Lønstrup Klint Formation in the KR01 thrust sheet (Fig. 21). The detailed section of the Rubjerg Knude Formation at the top of this log is uncertain due to poor exposure and difficulty of access. The Rubjerg Knude Formation exhibits variations in thickness throughout the Kramrende Section, and the description herein is based on scattered observations. A c. $1 \mathrm{~m}$ thick homogeneous, structureless sandy till caps the Kramrende Section. No preferred clast fabric has been recognised in the till, and its stratigraphic position is uncertain, although the occurrence of rare rhomb porphyry erratics may indicate an affinity with the Norwegian Ice (Kattegat Till Formation).

\section{Lønstrup Klint Formation}

In the Kramrende Section, the lower part of the Lønstrup Klint Formation mainly occurs in the Kramrende diapir, within the KR02-03 thrust sheets. Remobilisation of the mud has obliterated primary sedimentary structures, and the diapirism also affected the thrust sheet KR03, so that only primary bedding is recognisable in the uppermost part of the formation. The primary sedimentary structures of the upper part of the Lønstrup Klint Formation are reasonably preserved in the KR01 thrust sheet (Fig. 20), although the sediments here, dominantly constituting sandy turbidite beds (10$50 \mathrm{~cm}$ thick), are strongly affected by hydrodynamic brecciation creating ball-and-pillow structures (Fig. 68).

The top of the Lønstrup Klint Formation in the Kramrende Section is truncated by the L/R-unconformity, which displays an erosional relief of 1-2 m.

\section{Rubjerg Knude Formation}

The Rubjerg Knude Formation varies in thickness from only 6-8 $\mathrm{m}$ at the top of the KR03 thrust sheet to about $20 \mathrm{~m}$ in the upper part of the KR04 thrust sheet (it is absent in KR02). The main part of the formation comprises thick-bedded, large-scale cross-bedded, medium-grained light yellow-grey sand. Some beds are rich in heavy mineral sand, which occurs in parallel-laminated strata. In the KR04 thrust sheet, the heavy mineral beds are present about $6 \mathrm{~m}$ above the L/Runconformity and again about $15 \mathrm{~m}$ above the base. These beds have a characteristic content of small (0.1$1 \mathrm{~cm})$, grey clayey mud-clasts, which are interpreted to reflect erosion of muddy thrust sheet units in the vicinity of the depocentre.
Pedersen (1987) described deposits, referred here to the Rubjerg Knude Formation, that accumulated syntectonically in footwall growth synclines. The deposits were characterised as 'banana' shaped basins, and a similar type of sedimentary/structural feature occurs in the KR04 thrust sheet (Fig. 69). The Rubjerg Knude Formation at the top of the Kramrende Section can be regarded as a piggyback basin and the footwall syncline as a growth-fault syncline. At the top of the piggyback basin, large-scale trough cross-bedded sand is truncated by small satellite thrust faults (similar to that shown in Fig. 69), which are truncated by superposed c. $1 \mathrm{~m}$ thick trough cross-bedded sand beds. Three succeeding developments of this interference between thrusting and deposition reflect the syntectonic depositional dynamics of the piggyback basin.

\section{Structures}

Structures of significance in the Kramrende Section are described under the following headings: (1) thrust faults, and in particular associated footwall ramps and footwall synclines, (2) the Kramrende diapir, with the diapiric breccias and intrusive structures formed by mobilised mud, and (3) reverse faults, here interpreted as back-thrust faults.

\section{Thrust faults}

The KR01 thrust sheet is bounded by the hangingwall ramp and flat (KR01HWR and HWF) at the base, and the KR01 footwall ramp and flat at the top (KR01FWR and FWF). The wedge-shaped geometry of the KR01 tip implies that the KR01HWR had a low angle of inclination, dipping about $15^{\circ} \mathrm{N}$. Towards the trailing end of the thrust sheet, the ramp passes into a hanging-wall flat which is parallel to bedding in the Lønstrup Klint Formation. This thrust fault now dips at $25^{\circ} \mathrm{N}$, although it is a hanging-wall flat situated on a footwall flat. This is due to the fault-bend folding related to the thrusting in the trailing part of the Martørv Bakker Section.

At its trailing end, the KR01 thrust sheet is folded into a footwall syncline (Fig. 70). The bend of the northern limb in the syncline lifted the L/R-unconformity up to a position nearly $5 \mathrm{~m}$ higher than in the horizontal involute part of the fold, and the bedding in the Lønstrup Klint Formation was tilted into a nearly vertical position (Fig. 70). 


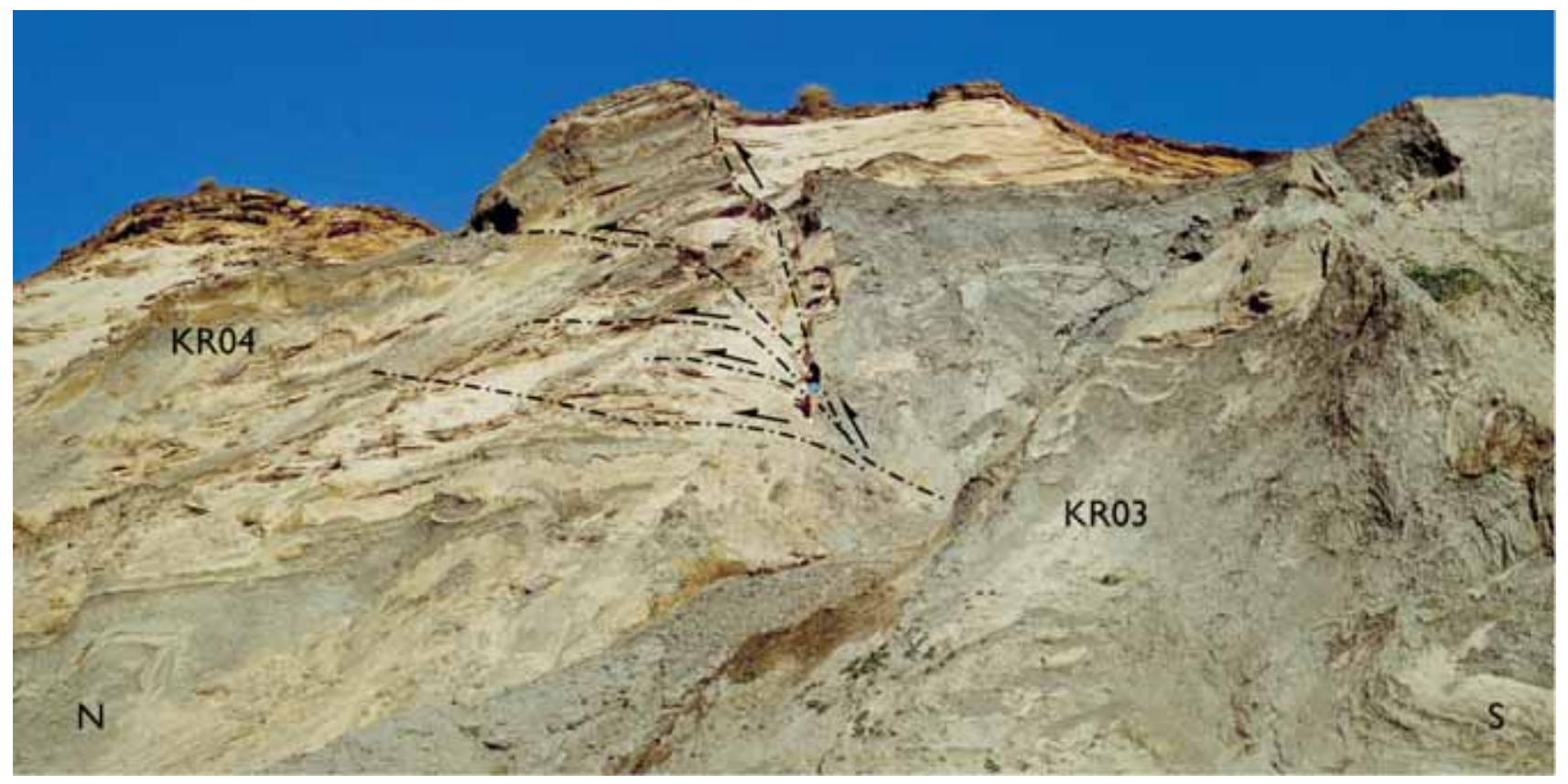

Fig. 72. Reverse fault-splay fan developed on the back of KR03 and also displacing the overlying KR04 thrust sheet. The structure is interpreted as a back-thrust fault-splay formed during the KR03 propagation over the upper footwall ramp situated on the back of KR02. Photograph: July 1994; figure at fault-splay centre for scale.

The KR02 thrust sheet was thrust up along a c. $25^{\circ}$ dipping footwall ramp (KR01FWR) onto the upper footwall flat above the Rubjerg Knude Formation of the KR01 thrust sheet. The KR02 thrust fault is apparently a hanging-wall flat which indicates a rather long displacement for thrusting. The top surface of KR02 is a footwall flat upon which the KR03 hanging-wall flat is situated, only bringing different stratigraphic levels of the Lønstrup Klint Formation into contact. The dip of the thrust fault is parallel to the dip of the KR02KR01 thrust fault. The footwall flat of the KR03 thrust sheet is overlain by a c. $80 \mathrm{~m}$ long hanging-wall flat of KR04. The Lønstrup Klint Formation is only about 8$10 \mathrm{~m}$ thick above the hanging-wall flat (KR04HWF), indicating a fairly long intermediate flat (at the $10 \mathrm{~m}$ level below the reference sufface). At the trailing end of KR04, the thickness increases indicating the presence of a hanging-wall ramp at the base of the thrust sheet, and a footwall syncline similar to that described in KR01 is present. In the upper part of the KR04 thrust sheet, the sediments deposited in the footwall growth syncline became overturned along the northern limb during translation of the hanging-wall ramp of BR01, as described above (Fig. 69).

\section{Kramrende diapir}

The Kramrende diapir constitutes the main part of KR02. The diapirism also affected the trailing end of KR01 (Fig. 70) as well as some parts of KR03. As shown in Fig. 71, mud of the lower part of the Lønstrup Klint Formation in KR02 became mobilised and intruded the overlying turbidite sand beds and also penetrated upwards into the overlying KR03 thrust sheet. Figure 70 illustrates a thrust fault penetrated by intrusive mud at the footwall ramp of KR01. Here, the mobilised mud from the steeply inclined northern limb of the footwall syncline intruded into the mud-breccia along and above the hanging-wall flat of KR02. A large part of the boundary between KR02 and KR03 was deformed in a similar way and the primary layering destroyed.

\section{Reverse faults}

In the Kramrende Section, significant steeply dipping reverse faults occur in the northern part of KR01 (Fig. 67), and in the middle part of the KR03 thrust sheet. The displacement is only about $30-50 \mathrm{~cm}$ on the steep south dipping faults in KR01; the spacing between the faults varies from 3-9 m, and often the faults can be traced down into the tectonic breccia above the 


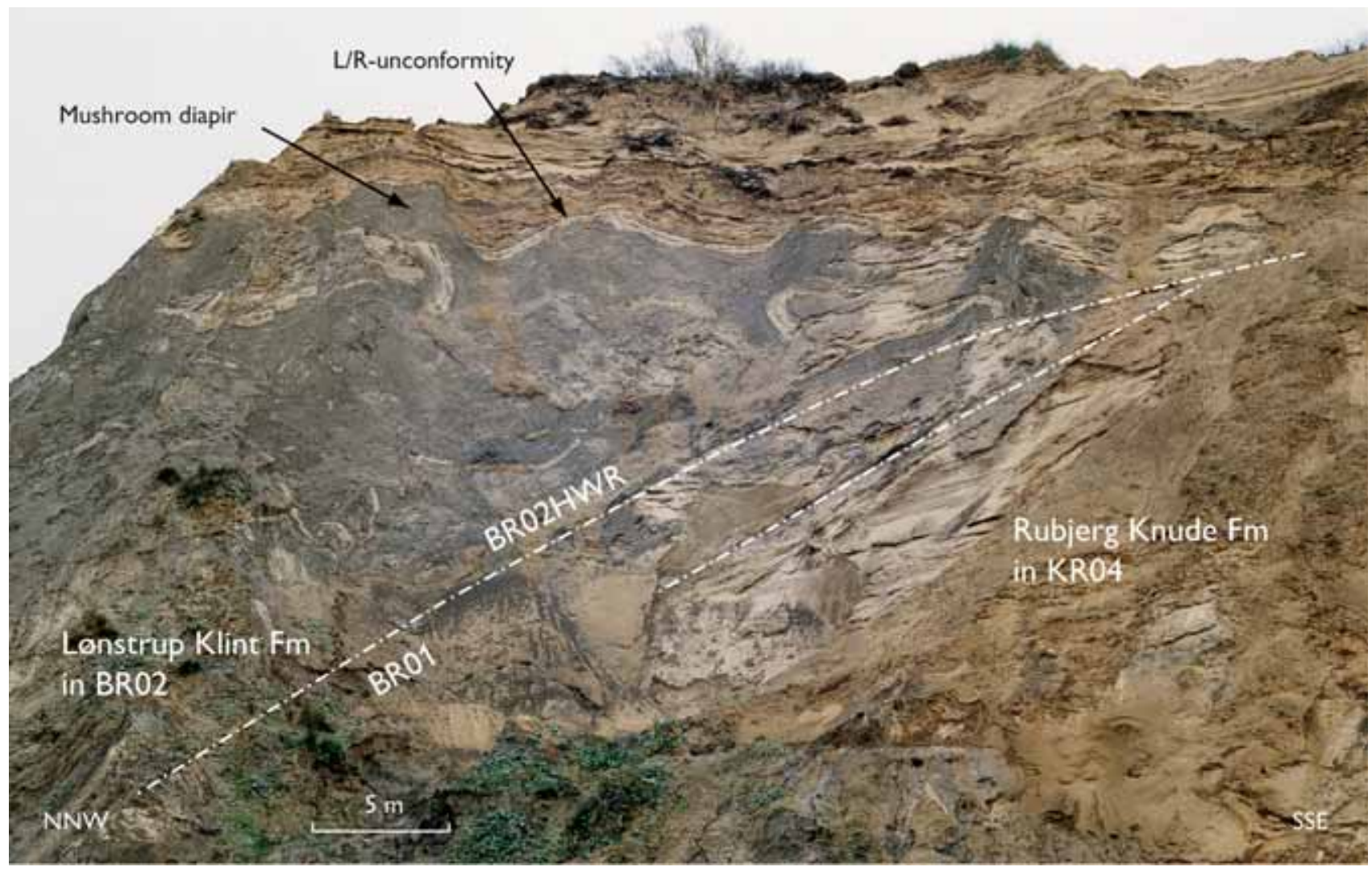

Fig. 73. The Brede Rende diapir in the frontal part of the Brede Rende Section. The frontal part of the BR02 thrust sheet was thrust up on its hanging-wall ramp (BR02HWR) along the footwall ramp, which turned into the KR04 footwall flat (KR04FWF). At an early stage of thrusting, probably while the hanging-wall ramp passed by a lower footwall hinge, diapirism developed. The mobilised mud also intruded the L/R-unconformity and formed mushroom-shaped diapirs in the Rubjerg Knude Formation. Photograph: June 1984.

hanging-wall flat. In the KR03 thrust sheet, the reverse faults form a fault splay fan with individual faults dipping moderately to steeply to the south (Fig. 72); displacement varies from about $20 \mathrm{~cm}$ up to about $3 \mathrm{~m}$.

The reverse faults appear to have formed during thrust-sheet propagation over a ramp hinge and are interpreted as back thrusts. A bend over a shallow dipping ramp will only result in minor displacement on steeply dipping back thrusts, whereas bending over steeply dipping ramps creates low-angle back thrusts with potentially greater displacements.

\section{Interpretation of structural development}

The balanced cross-section indicates that the KR01 thrust sheet was about $350 \mathrm{~m}$ long, of which a major part of the front tip has been eroded away. The amount of displacement is deduced from a series of balanced approximations to be $160 \mathrm{~m}$ (see Plate 2). The footwall ramp of KR01 is interpreted to root in the $30 \mathrm{~m}$ décollement level, which indicates that the lower hanging-wall ramp of KR01 was displaced onto the intermediate footwall flat above the trailing segment of MB04. Thus the lift and steep tilt of the northern limb in the KR01 footwall syncline is interpreted to have formed during the displacement of the lower hanging-wall ramp (KR01HWR) along the trailing-end footwall flat of MB04 (MB04FWF).

The tip of the KR02 thrust sheet has been eroded away. To avoid exaggeration, the thrust fault is interpreted to have continued only about $15 \mathrm{~m}$ up in the air further to the south, which implies that displacement of KR02 was in the order of $50 \mathrm{~m}$. The main part of the KR02 thrust sheet present in the cross-section is above the hanging-wall flat brought up from the 30 $\mathrm{m}$ décollement level. It is evident that the mobilised mud was derived from this low level and that it was activated in diapirism during the thrust-sheet propagation over the footwall ramps (KR01FWR) and its hinge bend.

It is difficult to estimate the displacement for the 